\title{
XPS and FT-IR Characterization of Selected Synthetic Corrosion Products of Zinc Expected in Neutral Environment Containing Chloride Ions
}

\author{
Juliusz Winiarski (iD, ${ }^{1}$ Włodzimierz Tylus, ${ }^{1}$ Katarzyna Winiarska, ${ }^{2}$ Irena Szczygiel, ${ }^{2}$ \\ and Bogdan Szczygiel ${ }^{1}$ \\ ${ }^{1}$ Department of Advanced Material Technologies, Faculty of Chemistry, Wrocław University of Science and Technology, \\ Wybrzeże Wyspiańskiego 27, PL50370 Wrocław, Poland \\ ${ }^{2}$ Department of Inorganic Chemistry, Faculty of Engineering and Economics, Wrocław University of Economics, \\ Komandorska 118/120 Street, PL53345 Wrocław, Poland
}

Correspondence should be addressed to Juliusz Winiarski; juliusz.winiarski@pwr.edu.pl

Received 22 February 2018; Revised 14 May 2018; Accepted 30 May 2018; Published 2 July 2018

Academic Editor: Jau-Wern Chiou

Copyright (c) 2018 Juliusz Winiarski et al. This is an open access article distributed under the Creative Commons Attribution License, which permits unrestricted use, distribution, and reproduction in any medium, provided the original work is properly cited.

$\mathrm{ZnO}, \mathrm{Zn}(\mathrm{OH})_{2}, \mathrm{Zn}_{5}(\mathrm{OH})_{8} \mathrm{Cl}_{2} \cdot \mathrm{H}_{2} \mathrm{O}, \mathrm{ZnCO}_{3}$, and $\mathrm{Zn}_{5}\left(\mathrm{CO}_{3}\right)_{2}(\mathrm{OH})_{6}$ synthetic powders were prepared by chemical or solid-state method. Their crystalline phase structure, thermal behavior, and morphology were examined. Characteristic infrared absorbance bands were estimated by means of FT-IR ATR spectroscopy. X-ray photoelectron spectroscopy (XPS) allowed to calculate the modified Auger parameters $\left(\alpha^{\prime}\right)$ thereof to 2010.2, 2009.3, 2009.4, 2009.7, and $2009.8 \mathrm{eV}$, respectively for $\mathrm{ZnO}, \mathrm{Zn}(\mathrm{OH})_{2}$, $\mathrm{Zn}_{5}(\mathrm{OH})_{8} \mathrm{Cl}_{2} \cdot \mathrm{H}_{2} \mathrm{O}, \mathrm{ZnCO}_{3}$, and $\mathrm{Zn}_{5}\left(\mathrm{CO}_{3}\right)_{2}(\mathrm{OH})_{6}$. Finally, comparison of surface composition may be crucial to evaluation of the unknown experimental spectra of corrosion products formed on the surface of zinc alloy coatings exposed in $\mathrm{NaCl}$ solution.

\section{Introduction}

Zinc-based alloys which contain molybdenum can be the potential substitute for toxic cadmium coatings or additional $\mathrm{Cr}(\mathrm{VI})$-based conversion coatings, due to the low harmfulness of $\mathrm{Mo}(\mathrm{VI})$ compounds present in the plating baths and the ability of molybdenum to form stable passive layer preventing chloride attack. The addition of molybdenum to zinc alloy coatings with the iron group metal seems to be interesting, and even in the 80s of twentieth century was undertaken research about the addition of Mo to binary zinc alloy coatings to form ternary $\mathrm{Zn}-\mathrm{Co}-\mathrm{Mo}$ [1] alloys.

In the more actual research $[2,3]$, the optimal conditions of the deposition of $\mathrm{Zn}-\mathrm{Co}-\mathrm{Mo}$ coatings have been defined. Recent work has been dedicated to determining the corrosion resistance of bright and homogeneous ternary $\mathrm{Zn}-\mathrm{Co}-\mathrm{Mo}$ alloy coatings in $\mathrm{NaCl}$ solution [3]. It has been demonstrated that the coatings with a content of about $2.7 \mathrm{wt} . \%$ Mo and $3.8 \mathrm{wt} . \%$ Co possess significantly better corrosion resistance than that of pure zinc coatings [3]. X-ray photoelectron spectroscopy (XPS) study revealed that the beneficial effect on the corrosion resistance of $\mathrm{Zn}$-Co-Mo coatings has a passive layer which, initially, is composed of $\mathrm{Zn}(\mathrm{OH})_{2}, \mathrm{ZnO}, \mathrm{Mo}(\mathrm{IV})$ oxide, and hydroxide and small amounts of $\mathrm{Co}_{3} \mathrm{O}_{4}$ [3]. For this reason, an attempt was made to investigate the corrosion mechanism of these coatings in a solution containing chloride ions, using the following techniques: infrared spectroscopy (FT-IR), the aforementioned XPS technique [4], and X-ray diffraction (XRD).

Further, own research led to the replacement of cobalt(II) compounds in electroplating baths with less harmful iron(II) compounds. Thanks to this, a method of obtaining $\mathrm{Zn}-\mathrm{Fe}-\mathrm{Mo}$ alloy coatings was successfully developed [5], and an effort was undertaken to investigate the mechanism of formation of passive layer and the layer of corrosion products [6].

It is well known that the layer of corrosion products can modify the kinetic of either anodic or cathodic reactions. Therefore, research studies focused on the analytical determination, chemical behavior, and properties of corrosion products are essential for understanding the corrosion mechanism of zinc alloy protective coatings with molybdenum. For 
detailed study on the corrosion of zinc and zinc alloy coatings, several analytical techniques should be used to get an insight into the bulk and the surface of the corrosion product layer. Generally, after short exposure in corrosive environment, the amount of corrosion products is often too low to be determined by X-ray diffraction, infrared spectroscopy, or Raman microscopy, and this was the problem encountered during the study of the surface composition of corroding $\mathrm{Zn}-\mathrm{Fe}-\mathrm{Mo}$ coatings. It was noted in own preliminary tests that the corrosion process of $\mathrm{Zn}-\mathrm{Fe}-\mathrm{Mo}$ coatings in $0.05 \mathrm{~mol} \cdot \mathrm{dm}^{-3}$ solution of $\mathrm{NaCl}$ is slow enough that the use of XRD and FT-IR techniques does not provide any information on the chemical composition of corrosion products. For this purpose, X-ray photoelectron spectroscopy (XPS) is commonly used [7]. However, the correct determination of the chemical states of the elements needs reference spectra of the expected compounds. According to the literature [8], during exposure in chloride environment, the layer of corrosion products may be formed by compounds such as $\mathrm{ZnO}, \mathrm{Zn}(\mathrm{OH})_{2}, \mathrm{ZnCO}_{3}$, and $\mathrm{Zn}_{5}(\mathrm{OH})_{8} \mathrm{Cl}_{2} \cdot \mathrm{H}_{2} \mathrm{O}$, wherein zinc hydroxide predominates in the chloride-containing medium [9]. However, the presence of both oxide and hydroxide forms and more complex structures of zinc were discussed in the literature [10]. In the XPS analysis, a specific marker of a chemical state of zinc in its corrosion products is the modified Auger parameter $\left(\alpha^{\prime}\right)$. It is noticeable that the values of $\alpha^{\prime}$ strongly vary among different literature references. Dake et al. [11] estimated for zinc hydroxide the $\alpha^{\prime}$ to be $2009.2 \mathrm{eV}$. Deroubaix and Marcus [12] revealed for this compound the values $2009.9 \mathrm{eV}$ and $2010.4 \mathrm{eV}$. It is interesting that the same authors reported similar $\alpha^{\prime}$ for zinc oxide (2010.2-2010.4 eV). All these literature discrepancies lead to the conclusion that zinc hydroxide is not stable during XPS analysis. Zinc hydroxide is well known to easily decompose to zinc oxide even at relatively low temperatures. Thus, this effect is more pronounced by the specific ultrahigh vacuum environment required for XPS analysis. This supposition is in agreement with the work of Duchoslav et al. [13] and our own study [4].

The main purpose of this work was gathering and comparing the characteristic XPS and IR spectra of synthetic $\mathrm{ZnO}, \mathrm{Zn}(\mathrm{OH})_{2}, \mathrm{Zn}_{5}(\mathrm{OH})_{8} \mathrm{Cl}_{2} \cdot \mathrm{H}_{2} \mathrm{O}, \mathrm{ZnCO}_{3}$, and $\mathrm{Zn}\left(\mathrm{CO}_{3}\right)_{2}(\mathrm{OH})_{6}$ powders, as corrosion products of zinc coatings that can be formed in the chloride environment. $\mathrm{X}$-ray diffraction, thermogravimetric analysis (TG/DTA), and scanning electron microscopy (SEM) were applied to characterize the synthesized zinc compounds. Finally, the recorded infrared spectra, photoelectron, and Auger electron spectra may be found to be of great importance in the future for an accurate IR and XPS evaluation of zinc corrosion products formed in $\mathrm{NaCl}$ environment on the surface of ternary zinc alloy coatings containing molybdenum, and for further investigation of the corrosion mechanism thereof.

\section{Materials and Methods}

2.1. Synthesis of the Powders. Zinc oxide, $\mathrm{ZnO}$, was prepared by the precipitation method at elevated temperature. Firstly, the solution of zinc sulfate $\left(50 \mathrm{~cm}^{3}\right.$ and $\left.1 \mathrm{~mol} \cdot \mathrm{dm}^{-3}\right)$ was heated to about $60^{\circ} \mathrm{C}$. Then, a portion of $2 \mathrm{~mol} \cdot \mathrm{dm}^{-3}$ $\mathrm{NaOH}$ solution was added with continuous stirring until the mixture reached $\mathrm{pH} \sim 13$. Stirring was continued for $30 \mathrm{~min}$, and then, the mixture was aged (without stirring) for 2 hours. The precipitate was subsequently filtered, washed several times with redistilled water in order to remove the soluble sulfates, and then dried at $50^{\circ} \mathrm{C}$ for 96 hours.

Zinc hydroxide, $\mathrm{Zn}(\mathrm{OH})_{2}$, was prepared by the precipitation method, based on the work of Shaporev et al. [14]. To the aqueous solution of the precipitant (sodium hydroxide, $50 \mathrm{~cm}^{3}$ and $0.15 \mathrm{~mol} \cdot \mathrm{dm}^{-3}$ ), a portion of $0.45 \mathrm{~mol} \cdot \mathrm{dm}^{-3}$ zinc nitrate solution was added. A precipitation agent was used in a tenfold molar excess relative to zinc ions. The obtained mixture was vigorously stirred for about $30 \mathrm{~min}$ at room temperature. The obtained white precipitate was filtered and washed several times with redistilled water and subsequently dried overnight at $50^{\circ} \mathrm{C}$.

Zinc hydroxide chloride, $\mathrm{Zn}_{5}(\mathrm{OH})_{8} \mathrm{Cl}_{2} \cdot \mathrm{H}_{2} \mathrm{O}$, was obtained by the precipitation method based on the experiment of Zhang et al. [15]. Aqueous solutions of zinc chloride $\left(50 \mathrm{~cm}^{3}\right.$ and $\left.1 \mathrm{~mol} \cdot \mathrm{dm}^{-3}\right)$ and $2 \mathrm{~mol} \cdot \mathrm{dm}^{-3}$ sodium hydroxide were prepared. The $\mathrm{NaOH}$ solution was added in portions to the $\mathrm{ZnCl}_{2}$ solution until $\mathrm{pH} \sim 6$. The mixture was heated up to $50^{\circ} \mathrm{C}$, stirred for $30 \mathrm{~min}$, and then aged for 2 hours. The precipitate was then filtered, washed several times with redistilled water, and dried at $50^{\circ} \mathrm{C}$ for 96 hours.

Anhydrous zinc carbonate, $\mathrm{ZnCO}_{3}$, was prepared by solid-state reaction at room temperature based on the experiment of $\mathrm{Wu}$ and Jing [16]. In this case, $\mathrm{ZnSO}_{4} \cdot 7 \mathrm{H}_{2} \mathrm{O}$, $\mathrm{NH}_{4} \mathrm{HCO}_{3}$, and polyethylene glycol were used as reactants. The components have been grinded for 1 hour in a mortar. The obtained mixture was hygroscopic and absorbing moisture from the air took the form of a paste. Before drying $\left(1 \mathrm{~h}, 110^{\circ} \mathrm{C}\right)$, the mixture was washed several times with redistilled water, to remove $\mathrm{SO}_{4}{ }^{2-}$ ions, and then by a small amount of an anhydrous ethanol.

Zinc hydroxide carbonate, $\mathrm{Zn}_{5}\left(\mathrm{CO}_{3}\right)_{2}(\mathrm{OH})_{6}$, was synthesized by precipitation from aqueous solution of zinc sulfate as the zinc ion source $\left(3 \mathrm{~mol} \cdot \mathrm{dm}^{-3}\right)$. The mixture of $3 \mathrm{~mol} \mathrm{dm}{ }^{-3} \mathrm{NH}_{4} \mathrm{HCO}_{3}$ and $1 \mathrm{~mol} \cdot \mathrm{dm}^{-3} \mathrm{NH}_{4} \mathrm{OH}$ was used as the precipitation agent. The precipitation process was conducted at room temperature. Substrates were placed on magnetic stirrer and mixed for $30 \mathrm{~min}$ (the final $\mathrm{pH}$ was 7.2). After that, the precipitate was filtered, washed several times with redistilled water, and dried at $50^{\circ} \mathrm{C}$ for 96 hours.

2.2. Characterization of the Powders. X-ray diffraction (XRD) was used to determine the phase structure of the synthesized particles. X-ray diffraction measurements at room temperature were performed with a Siemens D 5000 diffractometer using $\mathrm{CuK} \alpha$ radiation (scanning rate of $3-6^{\circ} \mathrm{min}^{-1}$ and an angle range of $2 \theta: 5-80^{\circ}$ ).

Thermal analysis (TG/DTA) was carried out with a derivatograph type 3427 (MOM, Hungary), from $20^{\circ} \mathrm{C}$ to $1100^{\circ} \mathrm{C}$ under air (heating rate: $7.5^{\circ} \mathrm{C} \mathrm{min}^{-1}$, reference material: alumina, platinum crucibles, Pt/PtRh10 thermocouple).

The morphology of the synthesized powdered samples was examined using a VEGA III (TESCAN) scanning electron microscope. All the samples were sputter-coated with a thin $(\sim 10 \mathrm{~nm})$ layer of carbon. 
X-ray photoelectron spectroscopy was done using a SPECS PHOIBOS 100 spectrometer and nonmonochromatic $\mathrm{Al}$ anode $(1486.7 \mathrm{eV})$ operating at $250 \mathrm{~W}$ for high-resolution spectra. The analyzed surface was of about $8 \times 8 \mathrm{~mm}^{2}$. Before analysis, the surfaces were cleaned by $\mathrm{Ar}^{+}$sputtering with low beam energy $\left(3 \mathrm{keV}, 5 \mu \mathrm{A} \cdot \mathrm{cm}^{-2}, 60 \mathrm{~s}\right)$. Spectra were processed and fitted by SPECLAB software using Gaussian-Lorentzian curve profile and Shirley baseline. The spectrometer energy scale was calibrated with $\mathrm{Au} 4 f_{7 / 2}, \mathrm{Ag} 3 d_{5 / 2}$, and $\mathrm{Cu} 2 \mathrm{p}_{3 / 2}$ lines at 84.2, 367.9, and $932.4 \mathrm{eV}$, respectively. The accuracy of the reported binding energies was $\pm 0.1 \mathrm{eV}$. C 1 s peak at $284.8 \mathrm{eV}$, as a contamination carbon, was used as reference for all spectra.

Infrared spectra of the synthesized powders were recorded using a PerkinElmer Frontier FT-IR spectrometer with PerkinElmer Universal ATR sampling accessory (diamond window) in the range of wavenumber from 4000 to $400 \mathrm{~cm}^{-1}, 128$ scans, and at a resolution of $4 \mathrm{~cm}^{-1}$. All spectra were ATR corrected.

\section{Results and Discussion}

3.1. Phase Structure and Thermal Behavior of Synthesized Particles. The XRD patterns of zinc oxidation species synthesized by chemical method are shown in Figure 1. Presented diffractograms confirmed almost all synthesized particles to be predominantly crystalline. Dominant diffraction peaks were assigned to the major crystalline phases from the JCPDSICDD database. The crystalline size of the prepared powders for the main diffraction peaks were calculated using the Scherrer equation [17] with the Scherrer constant $K=0.94$ and $\lambda=0.15406 \mathrm{~nm}$ (the wavelength of the radiation) in the Match! Software. As can be seen in the diffractogram for zinc oxide sample (Figure 1(a)), the reflections corresponding to zincite $(\mathrm{ZnO})$ phase are observed. The average crystalline size was almost $33 \mathrm{~nm}$. This phase crystallizes in the hexagonal structure (ICDD card number 36-1451). Other diffraction patterns of synthetic forms of zinc corrosion products obtained by the precipitation method are shown in Figures 1(b) and 1 (c). The diffractogram for $\mathrm{Zn}(\mathrm{OH})_{2}$ sample (Figure 1(b)) corresponds to ICDD card number 38-0385, whereas that for zinc hydroxide chloride sample (simonkolleite $\left.\left(\mathrm{Zn}_{5}(\mathrm{OH})_{8} \mathrm{Cl}_{2} \cdot \mathrm{H}_{2} \mathrm{O}\right)\right)$ corresponds to ICDD card number 07-0155 (Figure 1(c)). Calculated from the Scherrer equation, the average crystalline size was 72 and $132 \mathrm{~nm}$ for $\mathrm{Zn}(\mathrm{OH})_{2}$ and $\mathrm{Zn}_{5}(\mathrm{OH})_{8} \mathrm{Cl}_{2} \cdot \mathrm{H}_{2} \mathrm{O}$, respectively. As a result of the solidstate synthesis, the pure zinc carbonate with average crystalline size $23 \mathrm{~nm}$ was obtained. The diffractogram for $\mathrm{ZnCO}_{3}$ sample (Figure 1(d)) corresponds to smithsonite phase (JCPDS-ICDD 08-0449). Due to the low crystallinity (11 nm calculated from the Scherrer equation) of this compound, the diffractogram was presented on a $2: 1$ scale in relation to the other diffractograms. For this sample (Figure 1(e)), diffraction peaks correspond well to hydrozincite $\left(\mathrm{Zn}_{5}\left(\mathrm{CO}_{3}\right)_{2}(\mathrm{OH})_{6}\right)$ phase (JCPDS-ICDD 19-1458). The identification of obtained phases/powder was confirmed by further TG/DTA analysis and FT-IR spectroscopy.

The thermal behavior of obtained powders was investigated by TG/DTA heating in a temperature range from 20 to $1100^{\circ} \mathrm{C}$ (Figure 2). The DTA curve for the $\mathrm{ZnO}$ sample (Figure 2(a)) features neither exothermic nor endothermic peaks in the whole temperature range. As seen from TG curve, no mass loss was observed during the heat treatment process. Therefore, it can be concluded that no phase transformation appears when heating this sample as well as the $\mathrm{ZnO}$ powder is not hydrated. On the DTA curve for the $\mathrm{Zn}(\mathrm{OH})_{2}$ sample (Figure 2(b)), distinct endothermic peak at about $140^{\circ} \mathrm{C}$ appears. This peak is accompanied by a mass loss, which amounted to $30 \mathrm{mg}$. Due to the fact that this thermal effect starts at about $100^{\circ} \mathrm{C}$, it can be stated that it corresponds to hydroxide decomposition and transformation to zinc oxide which is more stable. No further effects were present at the TG/DTA curve (Figure 2(b)). The TG/DTA thermogram for $\mathrm{Zn}_{5}(\mathrm{OH})_{8} \mathrm{Cl}_{2} \cdot \mathrm{H}_{2} \mathrm{O}$ sample is more complicated (Figure 2(c)). At least three endothermic effects are present on the DTA curve. These effects are accompanied by corresponding mass losses (TG curve in Figure 2(c)). First one of them takes place between $100^{\circ} \mathrm{C}$ and $190^{\circ} \mathrm{C}$ with the weight loss amounted to $\sim 12 \mathrm{mg}(6.3 \%)$. The second endothermic peak occurs between $190^{\circ} \mathrm{C}$ and $210^{\circ} \mathrm{C}$. This effect is accompanied by a loss in mass of approx. $6 \mathrm{mg}(3.1 \%)$. The last one occurs at the temperature above $500^{\circ} \mathrm{C}$ with the mass loss about $18 \mathrm{mg}(9.5 \%)$. Based on the study of thermal decomposition of $\mathrm{Zn}_{5}(\mathrm{OH})_{8} \mathrm{Cl}_{2} \cdot \mathrm{H}_{2} \mathrm{O}$ [18], reaction in still atmosphere at a heating rate of $10^{\circ} \mathrm{min}^{-1}$ proceeds as follows:

$$
\begin{aligned}
& \qquad \mathrm{Zn}_{5}(\mathrm{OH})_{8} \mathrm{Cl}_{2} \cdot \mathrm{H}_{2} \mathrm{O} \stackrel{145-192^{\circ} \mathrm{C}}{\longrightarrow} 2 \beta-\mathrm{Zn}(\mathrm{OH}) \mathrm{Cl}+3 \mathrm{ZnO}+4 \mathrm{H}_{2} \mathrm{O} \uparrow \\
& \text { [theoretical weight loss } 13 \%] \stackrel{192-219^{\circ} \mathrm{C}}{\longrightarrow}\left[\mathrm{ZnCl}_{2}+\frac{1}{2} \mathrm{H}_{2} \mathrm{O}\right]+4 \mathrm{ZnO}+\frac{1}{2} \mathrm{H}_{2} \mathrm{O} \uparrow \\
& \text { [theoretical weight loss } \left.1.6 \%]^{219-602^{\circ} \mathrm{C}} \stackrel{\frac{1}{2}}{\longrightarrow} \mathrm{ZnCl}_{2} \uparrow+\mathrm{HCl} \uparrow\right]+\frac{1}{2} \mathrm{ZnO}+4 \mathrm{ZnO}
\end{aligned}
$$

[theoretical weight loss $19 \%$ ] $\equiv 4.5 \mathrm{ZnO}$

Based on the thermogram shown in Figure 2(c), it can be concluded that, between $100^{\circ} \mathrm{C}$ and $190^{\circ} \mathrm{C}$, transformation to $\beta-\mathrm{Zn}(\mathrm{OH}) \mathrm{Cl}$ and $\mathrm{ZnO}$ occurs. Next, above $190^{\circ} \mathrm{C}$, the $\beta-\mathrm{Zn}$
$(\mathrm{OH}) \mathrm{Cl}$ phase dehydroxylates to $\mathrm{ZnCl}_{2}$ and $\mathrm{ZnO}$. Above $220^{\circ} \mathrm{C}$, under these experimental conditions (heat rate $7.5^{\circ} \mathrm{min}^{-1}$ ), slightly larger amounts of both $\mathrm{ZnCl}_{2}$ and $\mathrm{H}_{2} \mathrm{O}$ are removed. 


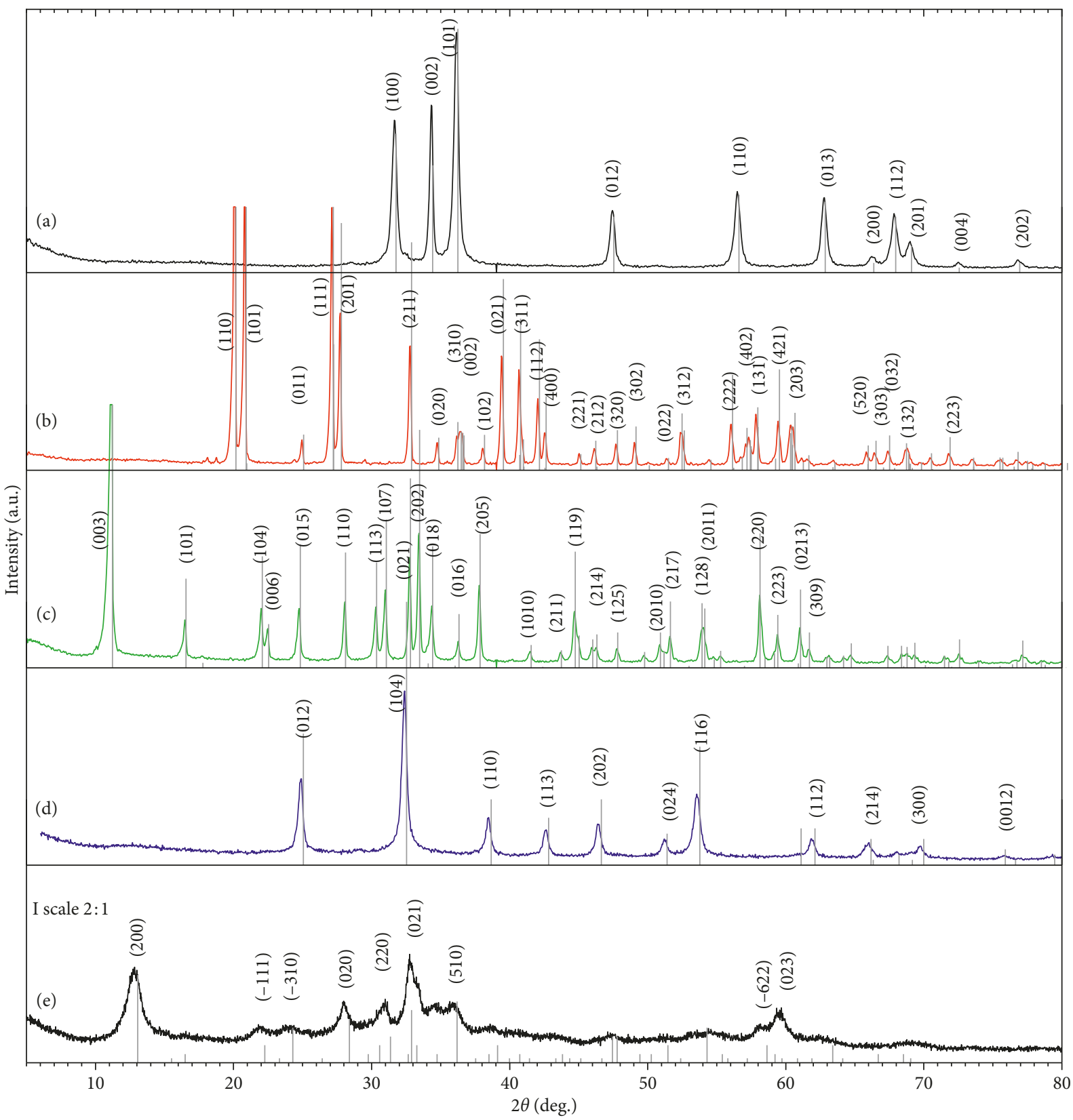

Figure 1: XRD patterns of synthesized $\mathrm{ZnO}(\mathrm{a}), \mathrm{Zn}(\mathrm{OH})_{2}(\mathrm{~b}), \mathrm{Zn}_{5}(\mathrm{OH})_{8} \mathrm{Cl}_{2} \cdot \mathrm{H}_{2} \mathrm{O}$ (c), $\mathrm{ZnCO}_{3}\left(\mathrm{~d}\right.$ ), and $\mathrm{Zn}_{5}\left(\mathrm{CO}_{3}\right)_{2}(\mathrm{OH})_{6}(\mathrm{e})$ powders prepared by the precipitation or solid-state $\left(\mathrm{ZnCO}_{3}\right)$ method.

A smaller fraction of $\mathrm{ZnCl}_{2}$ is hydrolyzed to $\mathrm{ZnO}$, which was observed as last endothermic peak at the TG/DTA curve. Finally at $530^{\circ} \mathrm{C}$, TG and DTA curves stabilize yielding a residue of $\mathrm{ZnO}$, with an overall experimental weight loss at about $20.5 \%$.
The DTA curves for $\mathrm{ZnCO}_{3}$ and $\mathrm{Zn}_{5}\left(\mathrm{CO}_{3}\right)_{2}(\mathrm{OH})_{6}$ are similar, and both exhibit one distinct endothermic peak at about $250^{\circ} \mathrm{C}$. This effect is related to the reactions (2) and (3), and those can be written as follows:

$$
\mathrm{ZnCO}_{3} \stackrel{250^{\circ} \mathrm{C}}{\longrightarrow} \mathrm{ZnO}+\mathrm{CO}_{2} \uparrow[\text { theoretical weight loss } 35.2 \%]
$$

$$
\mathrm{Zn}_{5}\left(\mathrm{CO}_{3}\right)_{2}(\mathrm{OH})_{6} \stackrel{240^{\circ} \mathrm{C}}{\longrightarrow} 5 \mathrm{ZnO}+2 \mathrm{CO}_{2} \uparrow+3 \mathrm{H}_{2} \mathrm{O} \uparrow \text { [theoretical weight loss } 26 \% \text { ] }
$$




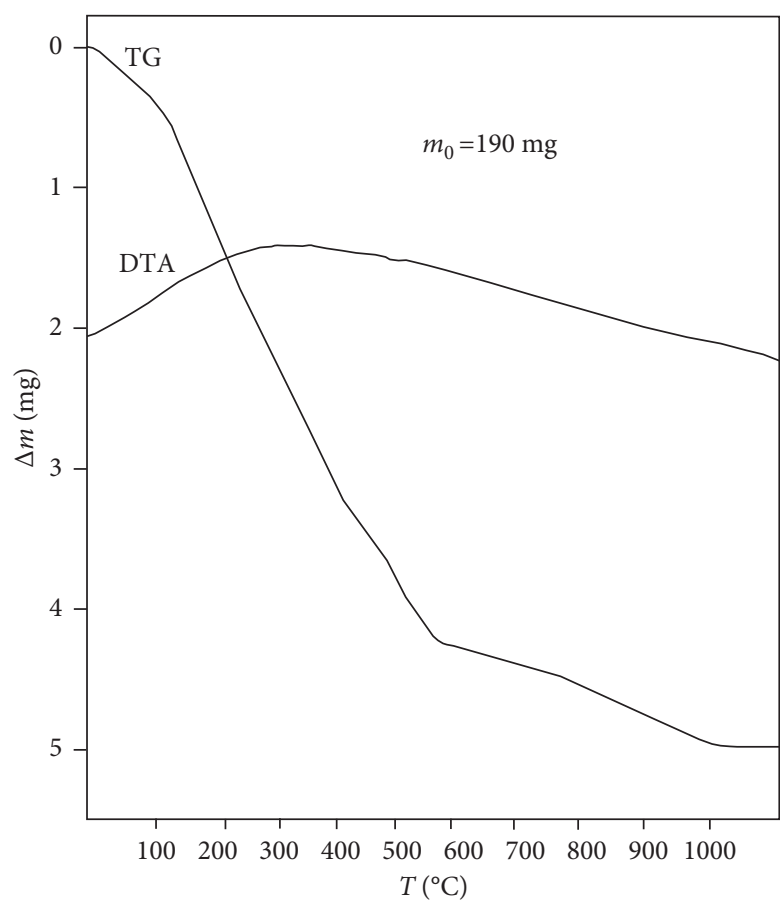

(a)

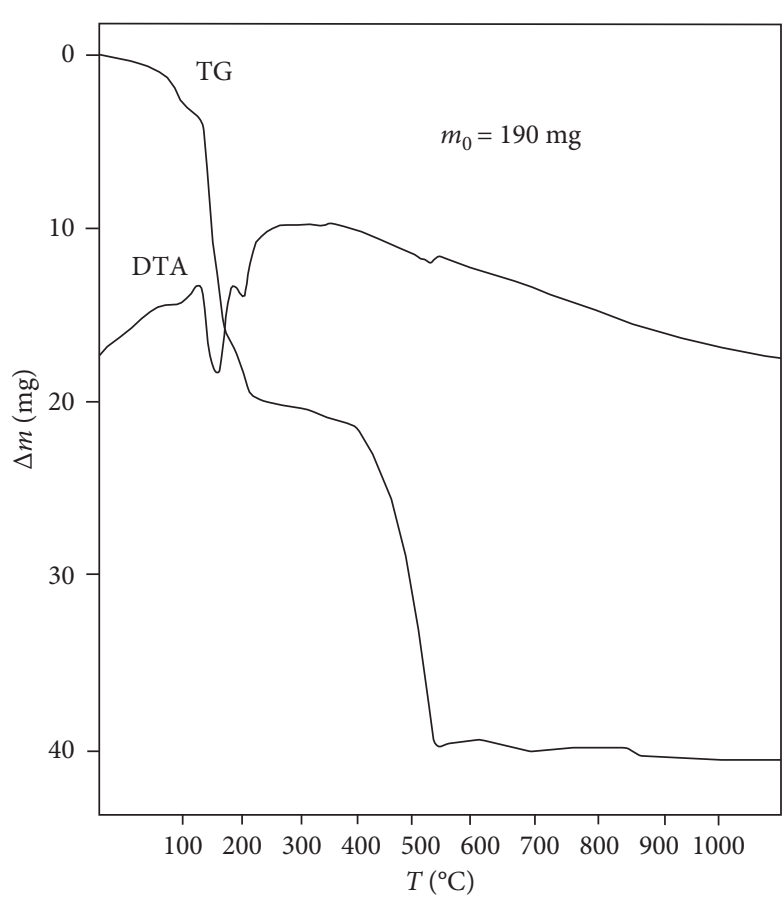

(c)

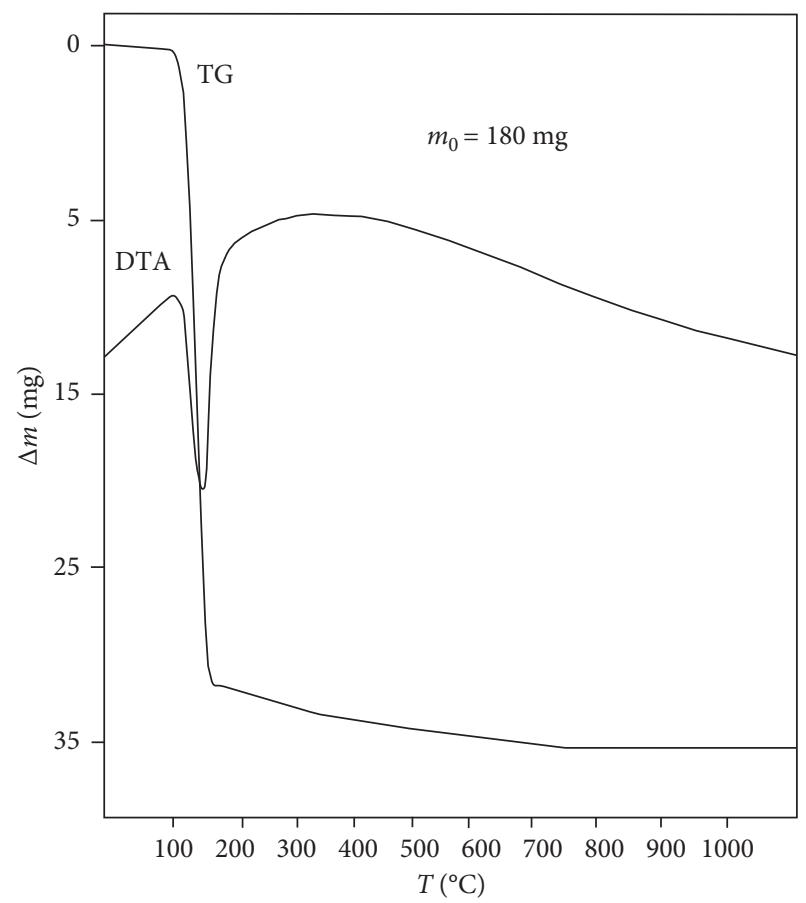

(b)

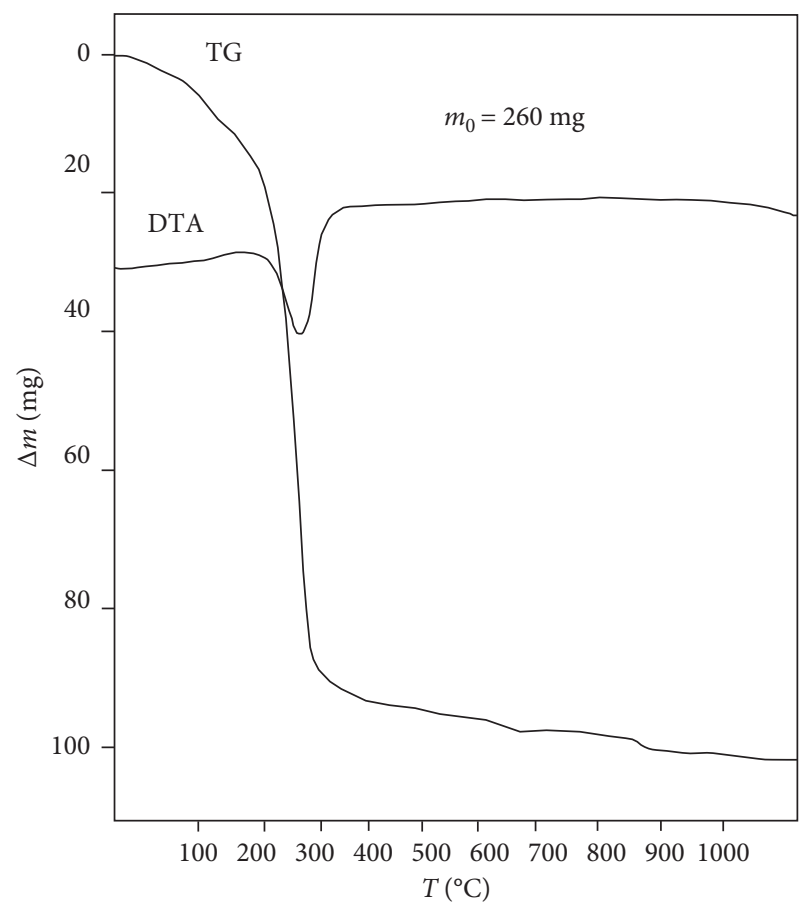

(d)

FIgUre 2: Continued. 


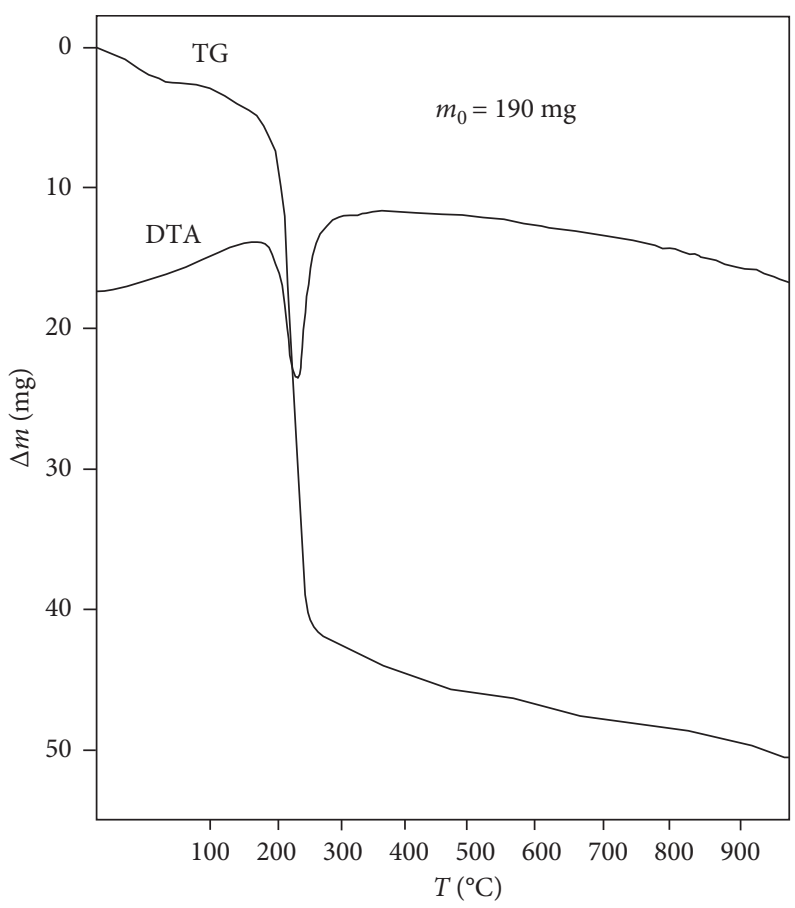

(e)

Figure 2: The TG/DTA curves for prepared powders $\mathrm{ZnO}(\mathrm{a}), \mathrm{Zn}(\mathrm{OH})_{2}(\mathrm{~b}), \mathrm{Zn}_{5}(\mathrm{OH})_{8} \mathrm{Cl}_{2} \cdot \mathrm{H}_{2} \mathrm{O}(\mathrm{c}), \mathrm{ZnCO}_{3}(\mathrm{~d})$, and $\mathrm{Zn}_{5}\left(\mathrm{CO}_{3}\right)_{2}(\mathrm{OH})_{6}(\mathrm{e})$. Initial mass $\left(m_{0}\right)$ is indicated in the figures.

In both cases, the weight loss increased slowly in the temperature interval up to $200^{\circ} \mathrm{C}$, whereas above this temperature, the thermal decomposition rate became fast. Greater weight loss occurs during decomposition of zinc carbonate as indicated from (2) and (3)The molar ratio of the solid to the gaseous phase $\left(\mathrm{CO}_{2}\right)$ formed during $\mathrm{ZnCO}_{3}$ decomposition is $1: 1$, and theoretical calculated mass loss is $35.2 \%$, while from one mole of $\mathrm{Zn}_{5}\left(\mathrm{CO}_{3}\right)_{2}(\mathrm{OH})_{6}$ is created 5 moles of gaseous products and theoretical calculated mass loss is $\sim 26 \%$. The experimental weight loss is close to the theoretical value, and for $\mathrm{Zn}_{5}\left(\mathrm{CO}_{3}\right)_{2}(\mathrm{OH})_{6}$, it amounted to $\sim 28 \%$. On the basis of the TG curve for $\mathrm{ZnCO}_{3}$, weight loss amounted to $36.5 \%$. Above the thermal decomposition temperature, no mass change was detected at the TG curve for both samples (Figures 2(d) and 2(e)).

\subsection{Microscopic and Spectroscopic Studies of the Synthesized Particles}

3.2.1. Morphology. SEM analysis revealed the synthesized particles to vary in morphology, crystal shape, and size (Figure 3). Zinc oxide powder has loose structure and it is composed of fine fiber or plate-like particles, few hundred of nanometers in size (Figure 3(a)). The particles of wulfingite $\left(\varepsilon-\mathrm{Zn}(\mathrm{OH})_{2}\right)$ have a granular shape and are covered by a fine deposit (Figure 3(b)). SEM microphotographs for simonkolleite $\left(\mathrm{Zn}_{5}(\mathrm{OH})_{8} \mathrm{Cl}_{2} \cdot \mathrm{H}_{2} \mathrm{O}\right)$ show that the obtained sheets have hexagonal structure, while the average size of these particles amounts to $1 \mu \mathrm{m}$ (Figure $3(\mathrm{c})$ ). Smithsonite $\left(\mathrm{ZnCO}_{3}\right)$ particles have nodular shape. Most of them have nanometric scale, but larger agglomerates are also visible (Figure 3(d)). Large and massive precipitates of hydrozincite $\left(\mathrm{Zn}_{5}\left(\mathrm{CO}_{3}\right)_{2}(\mathrm{OH})_{6}\right)$ have been formed by a number of loosely bonded nanoparticles (Figure 3(e)).

3.2.2. FT-IR Spectroscopy. ATR-IR spectra of the synthetic zinc alloy corrosion products are shown in Figure 4, while the main peaks of zinc compounds and corresponding vibration bonds, described based on current literature data, are listed in Table 1. Spectrum "a" in Figure 4 shows bands at about 570 and $403 \mathrm{~cm}^{-1}$ attributed to the formation of the stretching vibration of metal-oxygen $(\mathrm{Zn}-\mathrm{O})$ bonds. Typically, infrared spectra show characteristic bands of $\mathrm{ZnO}$ in the region from 680 up to $300 \mathrm{~cm}^{-1}$, which can be used for qualitative characterization and confirmation of the shape of $\mathrm{ZnO}$ particles [19].

The presence of bands at about $3390 \mathrm{~cm}^{-1}$ was characteristic for the stretching vibration of intermolecular hydrogen bond $(\mathrm{OH})$ existing between the adsorbed water molecules. Also, the bond characteristic for $\mathrm{OH}$ stretching vibration appears at about $3200 \mathrm{~cm}^{-1}$ on the ATR spectrum for zinc hydroxide (spectrum " $b$ " in Figure 4). Other modes originating from $\mathrm{OH}$ such as $\mathrm{ZnOH}$ bending and $\mathrm{OH}$ libration are observed at lower wavenumbers $\left(1100-750 \mathrm{~cm}^{-1}\right)$. The bands in the range from 1000 to $1120 \mathrm{~cm}^{-1}$ could be interpreted as motion of hydrogen atoms perpendicular to the connection line of the two nearest metal ions in type $\mathrm{OM}_{2} \mathrm{H}$ unit, whereas the bands in the range from 700 to $800 \mathrm{~cm}^{-1}$ could be interpreted as those parallel in relation to tangential to this line [20]. Zinc hydroxide chloride spectrum shows 


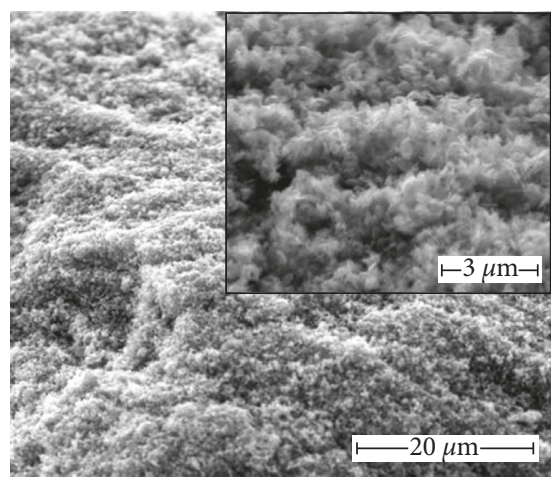

(a)

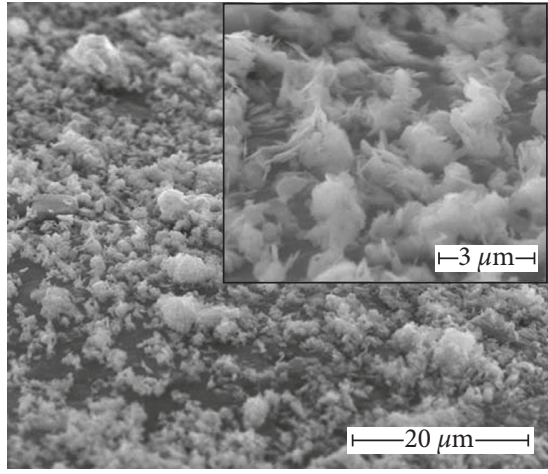

(c)

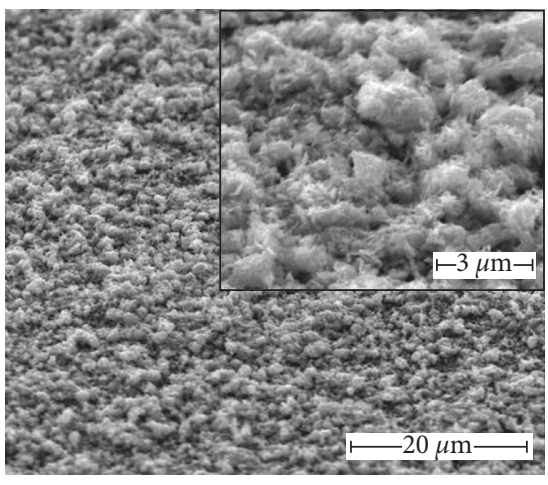

(b)

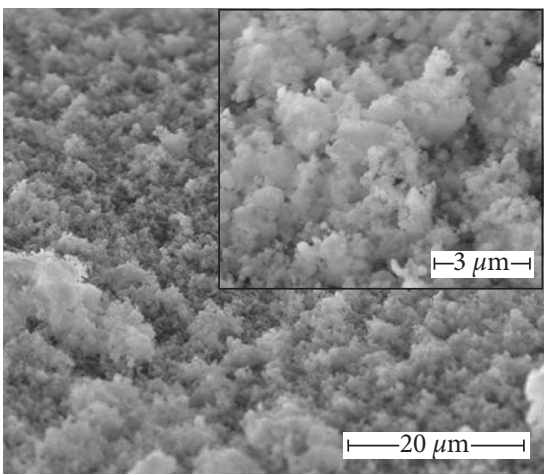

(d)

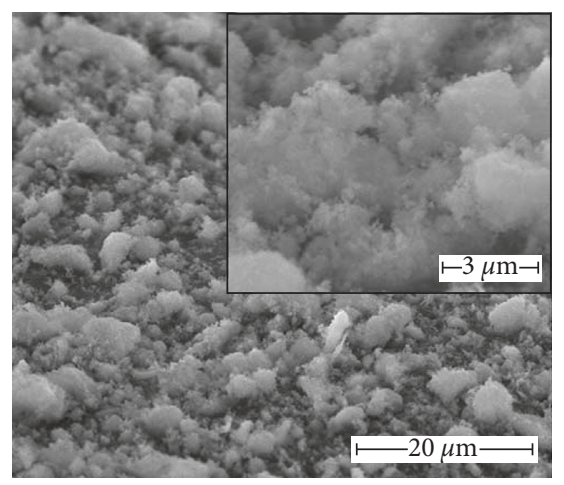

(e)

Figure 3: SEM microphotographs of $\mathrm{ZnO}(\mathrm{a}), \mathrm{Zn}(\mathrm{OH})_{2}(\mathrm{~b}), \mathrm{Zn}_{5}(\mathrm{OH})_{8} \mathrm{Cl}_{2} \cdot \mathrm{H}_{2} \mathrm{O}(\mathrm{c}), \mathrm{ZnCO}_{3}(\mathrm{~d})$, and $\mathrm{Zn}_{5}\left(\mathrm{CO}_{3}\right)_{2}(\mathrm{OH})_{6}(\mathrm{e})$ powders prepared by the precipitation or solid-state $\left(\mathrm{ZnCO}_{3}\right)$ method.

characteristic peaks at about 1040, 900, and $715 \mathrm{~cm}^{-1}$, which have also previously been described by Srivastava and Secco [21]. The bands for translational/lattice modes are visible below $600 \mathrm{~cm}^{-1}$ in Figure 4, spectrum " $c$ ". In this case, the hydrogen bonds are formed between $\mathrm{H}_{2} \mathrm{O}$ molecules (hydrogen bond donors) and the $\mathrm{OH}$ groups (hydrogen bond acceptors). This could be manifested by the appearance of splitting and broadening of the band at approximately $3450 \mathrm{~cm}^{-1}$. In the ATR spectra of zinc carbonate, the very strong bands occurred at about $1400 \mathrm{~cm}^{-1}$, whereas for hydrozincite, two bands are observed (at about 1500 and $1390 \mathrm{~cm}^{-1}$ ). These bands may be assigned to $v_{3}\left(\mathrm{CO}_{3}\right)^{2-}$ antisymmetric stretching modes. As explained by Hales and Frost [22], the difference of number of bands in this spectral region (between zinc carbonate and hydrozincite) is due to the symmetry reduction of the hydrozincite. The mode for $v_{2}\left(\mathrm{CO}_{3}\right)^{2-}$ for zinc carbonate is slightly shifted towards higher values of wavenumber $\left(\sim 870 \mathrm{~cm}^{-1}\right)$. Multiple bands are observed for $v_{4}\left(\mathrm{CO}_{3}\right)^{2-}$ in the hydrozincite spectrum (spectrum " $\mathrm{e}$ " in Figure 4), while for zinc carbonate, only one band is present in the spectrum. Similarly, as for previously described compounds, bands bellow $600 \mathrm{~cm}^{-1}$ could be assigned to lattice modes. The band characteristics for $\mathrm{OH}$ stretching vibration are very weak for zinc carbonate, whereas for hydrozincite, very broad band is observed at $3300 \mathrm{~cm}^{-1}$. This value is in accordance with previously described findings in the literature $[23,26]$. Other strong intensity bands are observed at about 1040 and $950 \mathrm{~cm}^{-1}$ and may be assigned to $\mathrm{OH}$ librations. 


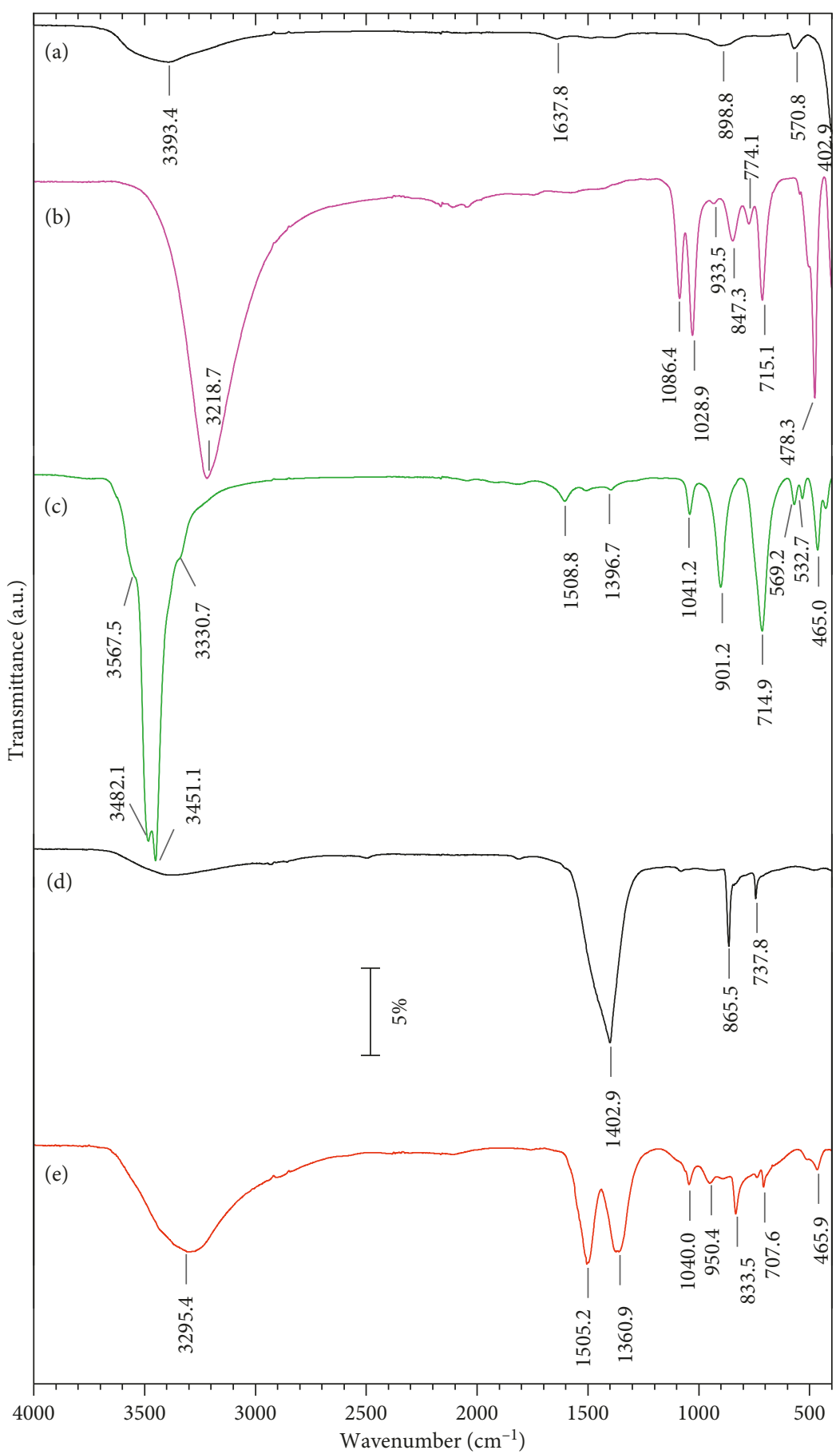

Figure 4: FT-IR ATR spectra of $\mathrm{ZnO}(\mathrm{a}), \mathrm{Zn}(\mathrm{OH})_{2}(\mathrm{~b}), \mathrm{Zn}_{5}(\mathrm{OH})_{8} \mathrm{Cl}_{2} \cdot \mathrm{H}_{2} \mathrm{O}$ (c), $\mathrm{ZnCO}_{3}$ (d), and $\mathrm{Zn}_{5}\left(\mathrm{CO}_{3}\right)_{2}(\mathrm{OH})_{6}$ (e) powders prepared by the precipitation method.

3.2.3. XPS Surface Analysis. The identification of chemical bonds between zinc and oxygen in oxidation products of zinc is the main problem in qualitative and quantitative surface analysis by means of X-ray photoelectron spectroscopy. This research task is not difficult, when two completely different (in terms of binding energy) oxidized zinc forms are considered, for example, $\mathrm{ZnO}$ and $\mathrm{Zn}(\mathrm{OH})_{2}$. When compounds with more complex structure, for example, hydroxychlorides, hydroxycarbonates, and so on, are present in addition to the abovementioned $\mathrm{ZnO}$ and $\mathrm{Zn}(\mathrm{OH})_{2}$, their quantitative differentiation begins to be really difficult. This situation occurs during corrosion of zinc coatings in the real systems, that is, chloride-containing environment where corrosion products are a mixture of zinc: oxide, hydroxychloride, hydroxycarbonate, and hydroxide [9]. Therefore, very useful would be knowledge of standard photoelectron spectra of individual oxidized zinc compounds. 
TABLE 1: Results of FT-IR ATR spectra for the synthetic products of zinc corrosion: $\mathrm{ZnO}, \mathrm{Zn}(\mathrm{OH})_{2}, \mathrm{Zn}_{5}(\mathrm{OH})_{8} \mathrm{Cl}_{2} \cdot \mathrm{H}_{2} \mathrm{O}, \mathrm{ZnCO}_{3}$, and $\mathrm{Zn}_{5}\left(\mathrm{CO}_{3}\right)_{2}(\mathrm{OH})_{6}$.

\begin{tabular}{|c|c|c|c|}
\hline Compound & Band assignment & Peak center $\left(\mathrm{cm}^{-1}\right)$ & Literature peak region $\left(\mathrm{cm}^{-1}\right)$ \\
\hline \multirow{5}{*}{$\mathrm{ZnO}$} & $\mathrm{OH}$ stretching vibration & $3393.4(\mathrm{~m})$ & $3620-2950[19]$ \\
\hline & $\mathrm{C}=\mathrm{O}$ stretching vibration & $1637.8(\mathrm{vw})$ & $1635[19]$ \\
\hline & $\mathrm{C}=\mathrm{O}$ stretching vibration & $898.8(\mathrm{~m})$ & $875[19]$ \\
\hline & $\mathrm{Zn}-\mathrm{O}$ lattice & $570.8(\mathrm{~s})$ & $300-650[19]$ \\
\hline & Zn-O lattice & $402.9(\mathrm{~s})$ & \\
\hline \multirow{8}{*}{$\mathrm{Zn}(\mathrm{OH})_{2}$} & $\mathrm{OH}$ stretching vibration & 3218.7 (vs) & $3250-3100[20], 3260[21]$ \\
\hline & $\mathrm{OH}$ librations & 1086.4 (vs) & $1115-1060[20], 1080[21]$ \\
\hline & $\mathrm{OH}$ librations & 1028.9 (vs) & $1040[20], 1025[21]$ \\
\hline & $\mathrm{OH}$ librations & $933.5(\mathrm{~m})$ & $947[20]$ \\
\hline & OH librations & $847.3(\mathrm{~s})$ & $844[20], 830[21]$ \\
\hline & $\mathrm{OH}$ librations & $774.1(\mathrm{~m})$ & $772[20], 750[21]$ \\
\hline & $\mathrm{OH}$ librations & 715. 1(vs) & $739[20], 715$ [21] \\
\hline & $\mathrm{Zn}-\mathrm{O}$ asymmetric stretching & 478.3 (vs) & Below 550 [20] \\
\hline \multirow{10}{*}{$\mathrm{Zn}_{5}(\mathrm{OH})_{8} \mathrm{Cl}_{2} \cdot \mathrm{H}_{2} \mathrm{O}$} & $\mathrm{OH}$ stretching vibration & $3567.5(\mathrm{~s})$ & $3600-3260[21]$ \\
\hline & $\mathrm{OH}$ stretching vibration & 3482.1 (vs) & 3588 and 3570 [22] \\
\hline & $\mathrm{H}_{2} \mathrm{O}$ bending & 3451.1 (vs) & $3495-3455[21,22]$ \\
\hline & $\mathrm{H}_{2} \mathrm{O}$ bending & $3330.7(\mathrm{~s})$ & \\
\hline & $\mathrm{H}_{2} \mathrm{O}$ bending & $1604.1(\mathrm{~m})$ & $1601[22]$ \\
\hline & $\mathrm{OH}$ bending & $1041.2(\mathrm{~s})$ & $1035[21]$ \\
\hline & $\mathrm{ZnOH}$ librations & 901.2 (vs) & 895 [21], 906 [22] \\
\hline & $\mathrm{ZnOH}$ librations & 714.9 (vs) & 715 [21], 717 [22] \\
\hline & $\mathrm{Zn}-\mathrm{O}$ lattice mode & $569.2(\mathrm{~s})$ & Below 570 [22] \\
\hline & $\mathrm{Zn}$-O lattice mode & $532.7(\mathrm{~s})$ & \\
\hline \multirow{3}{*}{$\mathrm{ZnCO}_{3}$} & $\mathrm{CO}_{3} v_{3}$ & 1402.9 (vs) & $1485-1320[23]$ \\
\hline & $\mathrm{CO}_{3} v_{2}$ & 865.4 (vs) & $890-850[23]$ \\
\hline & $\mathrm{CO}_{3} v_{4}$ & $737.8(\mathrm{~s})$ & $750-710[23]$ \\
\hline \multirow{9}{*}{$\mathrm{Zn}_{5}\left(\mathrm{CO}_{3}\right)_{2}(\mathrm{OH})_{6}$} & $\mathrm{OH}$ stretching vibration & 3295.4 (vs) & $3560-2750[23], 3402[24]$ \\
\hline & $\mathrm{CO}_{3} v_{3}$ component 1 & 1505.2 (vs) & $1600-1200[25], 1503$ [24], 1395 \\
\hline & $\mathrm{CO}_{3} v_{3}$ component 2 & 1360.9 (vs) & {$[24], 1383[23]$} \\
\hline & $\mathrm{OH}$ bending & $1046.7(\mathrm{~s})$ & $1070-1035[23], 1046$ [24] \\
\hline & $\mathrm{OH}$ bending & 950.4 (vs) & $949[23], 951[24]$ \\
\hline & $\mathrm{CO}_{3} v_{2}$ & 833.5 (vs) & $832[23], 833[24]$ \\
\hline & $\mathrm{CO}_{3} v_{4}$ & $737.8(\mathrm{~m})$ & $737[23]$ \\
\hline & $\mathrm{CO}_{3} v_{4}$ & 707.6 (vs) & 707 [23], 708 [24] \\
\hline & $\mathrm{Zn}-\mathrm{O}$ lattice mode & 465.9 (vs) & $469[25], 483[24]$ \\
\hline
\end{tabular}

${ }^{*}$ Peak intensity: vs, very strong; s, strong; m, moderate; $\mathrm{w}$, weak; vw, very weak.

In order to solve this problem, both XPS core-level spectra and Auger spectra for synthetic zinc oxidation products were recorded. $\mathrm{O} 1 \mathrm{~s}$ photoelectron spectra for synthetic $\mathrm{ZnO}$ and $\mathrm{Zn}(\mathrm{OH})_{2}$ powders (Figure 5) show that their surface is not homogeneous. For $\mathrm{ZnO}$ powder, which was analyzed "as received," the spectrum O 1s was deconvoluted taking into account the presence of three components: (1) dominant lattice oxide- $\mathrm{ZnO}$, (2) $\mathrm{Zn}(\mathrm{OH})_{2}$, and (3) surface and/or crystal water. On the $\mathrm{O} 1 \mathrm{~s}$ spectrum of $\mathrm{Zn}(\mathrm{OH})_{2}$ synthetic powder, the $\mathrm{OH}^{-}$component predominates. However, the peak asymmetry towards lower BE suggests the presence of the remnants of $\mathrm{ZnO}$. Therefore, the accurate determination of zinc-oxygen binding energy in $\mathrm{Zn}(\mathrm{OH})_{2}$ was achieved by $\mathrm{Ar}^{+}$sputtering. After $\mathrm{Ar}^{+}$sputtering, the component " $\mathrm{ZnO}$ " became more intense $\left(\mathrm{Zn}(\mathrm{OH})_{2}\right.$ to $\mathrm{ZnO}$ photoreduction phenomenon). This fact made the deconvolution easier (Figure 5(b)). What is interesting is that $\mathrm{Ar}^{+}$ sputtering of the surface of $\mathrm{ZnO}$ synthetic powder did not result in a significant loss of $\mathrm{OH}^{-}$component (photoreduction was not observed this time).
Zinc shows only a small binding energy shift in the $\mathrm{Zn}$ $2 \mathrm{p}_{3 / 2}$ region $(1021 \mathrm{eV}-1023 \mathrm{eV})$. Besides, peak width may broaden when more than one $\mathrm{Zn}$ species are present. Therefore, the correct identification of zinc chemical bonds performed only on the main $\mathrm{Zn} 2 \mathrm{p}_{3 / 2}$ line is unreliable. Despite this, $\mathrm{Zn} 2 \mathrm{p}_{3 / 2}$ spectra for $\mathrm{ZnO}$ and $\mathrm{Zn}(\mathrm{OH})_{2}$ powders are presented in Figure 6.

These spectra in Figure 6 were deconvoluted on the basis of previously estimated (by means of $\mathrm{O} 1 \mathrm{~s}$ spectra) $\mathrm{ZnO}$ : $\mathrm{Zn}(\mathrm{OH})_{2}$ ratios. Also, in this case, the $\mathrm{Ar}^{+}$sputtering of the surface was useful in determining the binding energy of $\mathrm{Zn}$ $2 \mathrm{p}_{3 / 2}$ photoelectron bonds (Table 2). As it was mentioned earlier, chemical state differentiation by XPS on the basis of $\mathrm{Zn} 2 \mathrm{p}_{3 / 2}$ main line only can be difficult or even impossible due to a small binding energy shift between $\mathrm{Zn}^{0}, \mathrm{ZnO}$, $\mathrm{Zn}(\mathrm{OH})_{2}, \mathrm{ZnCO}_{3}$, and $\mathrm{Zn}_{5}(\mathrm{OH})_{6}\left(\mathrm{CO}_{3}\right)_{2}$ especially occurring at the same time. For that reason, the interpretation of the Auger $\mathrm{Zn} \mathrm{L}_{3} \mathrm{M}_{45} \mathrm{M}_{45}$ main lines might be useful (spectra not included) because of larger chemical shifts (CS- $\left.\mathrm{L}_{3} \mathrm{M}_{45} \mathrm{M}_{45}\right)$. The utility of Zn LMM spectral line becomes obvious if zinc 


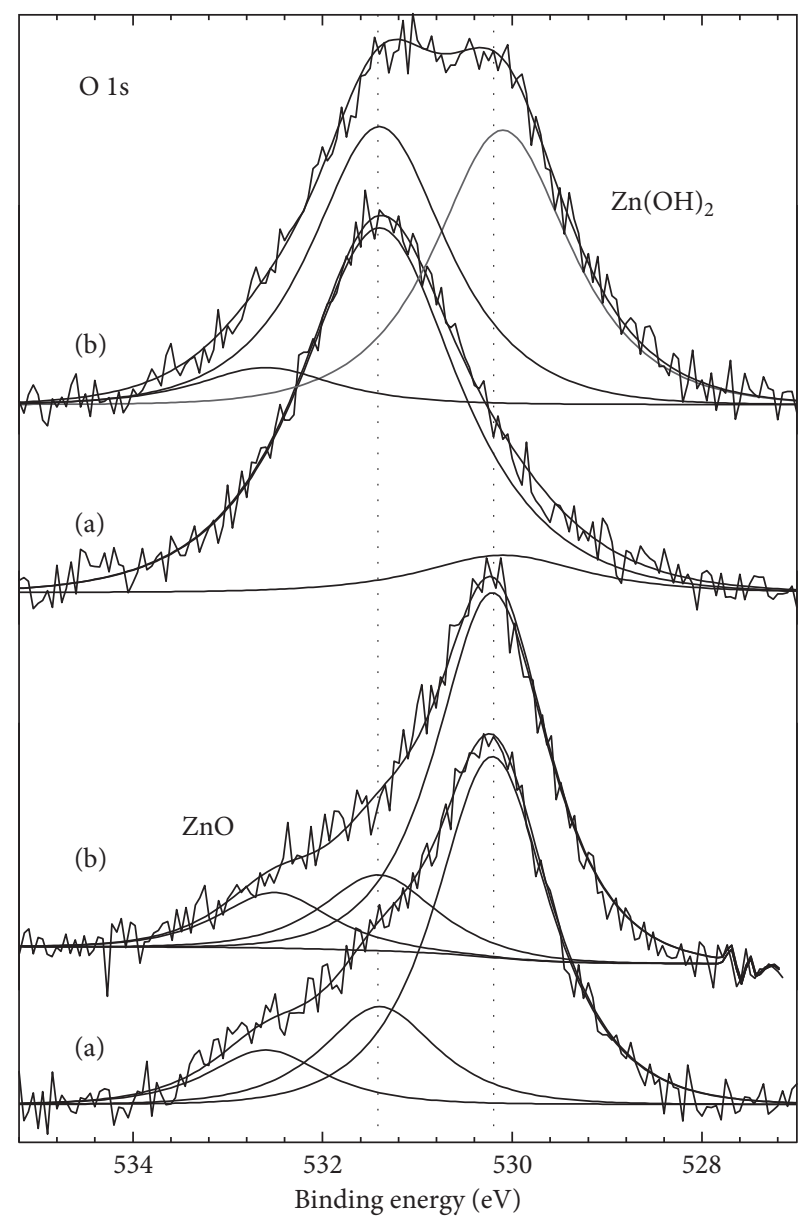

FIgUre 5: $\mathrm{O}$ 1s photoelectron spectra for $\mathrm{ZnO}$ and $\mathrm{Zn}(\mathrm{OH})_{2}$ before (a) and after (b) $\mathrm{Ar}^{+}$sputter cleaning.

is buried (under carbon, for example). Then, Zn LMM peak may be observed even if $\mathrm{Zn} 2 \mathrm{p}$ is not visible. Similarly, $\mathrm{Zn} 3 \mathrm{p}$ (of very high kinetic energy) may be observed even if $\mathrm{Zn} 2 \mathrm{p}$ is not visible. These statements result from the sampling depth of $\mathrm{Zn} 2 \mathrm{p}_{3 / 2}$, Zn LMM, and Zn $3 \mathrm{p}$ photoelectrons. These values, conventionally calculated in XPS as $3 \lambda_{x}{ }^{y}$ (where $x$ is the photoelectron and $y$ is the medium in which the electron moves), are respectively $3 \lambda_{\mathrm{Zn} 2 \mathrm{p} 3} \mathrm{ZnO}=2.4 \mathrm{~nm}$, $3 \lambda_{\mathrm{ZnLMM}}{ }^{\mathrm{ZnO}}=6 \mathrm{~nm}$, and $3 \lambda_{\mathrm{Zn} 3 \mathrm{p}}{ }^{\mathrm{ZnO}}=8 \mathrm{~nm}$ [27]. The values of $\mathrm{KE}$ for $\mathrm{Zn} \mathrm{L}_{3} \mathrm{M}_{45} \mathrm{M}_{45}$ as well as modified Auger parameter $\left(\alpha^{\prime}\right)$ are shown in Table 2 .

Auger parameter is very useful energy parameter for identifying the chemical state of elements where chemical shift is very small or comparable with the energy resolution of the instrument. This modified Auger parameter $\left(\alpha^{\prime}\right)$ is independent of the X-ray energy used as well as independent of charging effect. This property makes it easier to compare the results from the work of other authors, and what has been done in the current work. The calculated $\alpha^{\prime}$ parameter values indicate very high compliance with the literature data (Table 2). To our knowledge, the data for $\mathrm{Zn}_{5}(\mathrm{OH})_{8} \mathrm{Cl}_{2} \cdot \mathrm{H}_{2} \mathrm{O}$ as typical corrosion product of zinc are presented here for the first time.

The $\mathrm{Zn} 3 \mathrm{p}$ spectra are no longer as significant as $\mathrm{Zn} 2 \mathrm{p}$, due to the almost 6 -fold lower value of the relative sensitivity

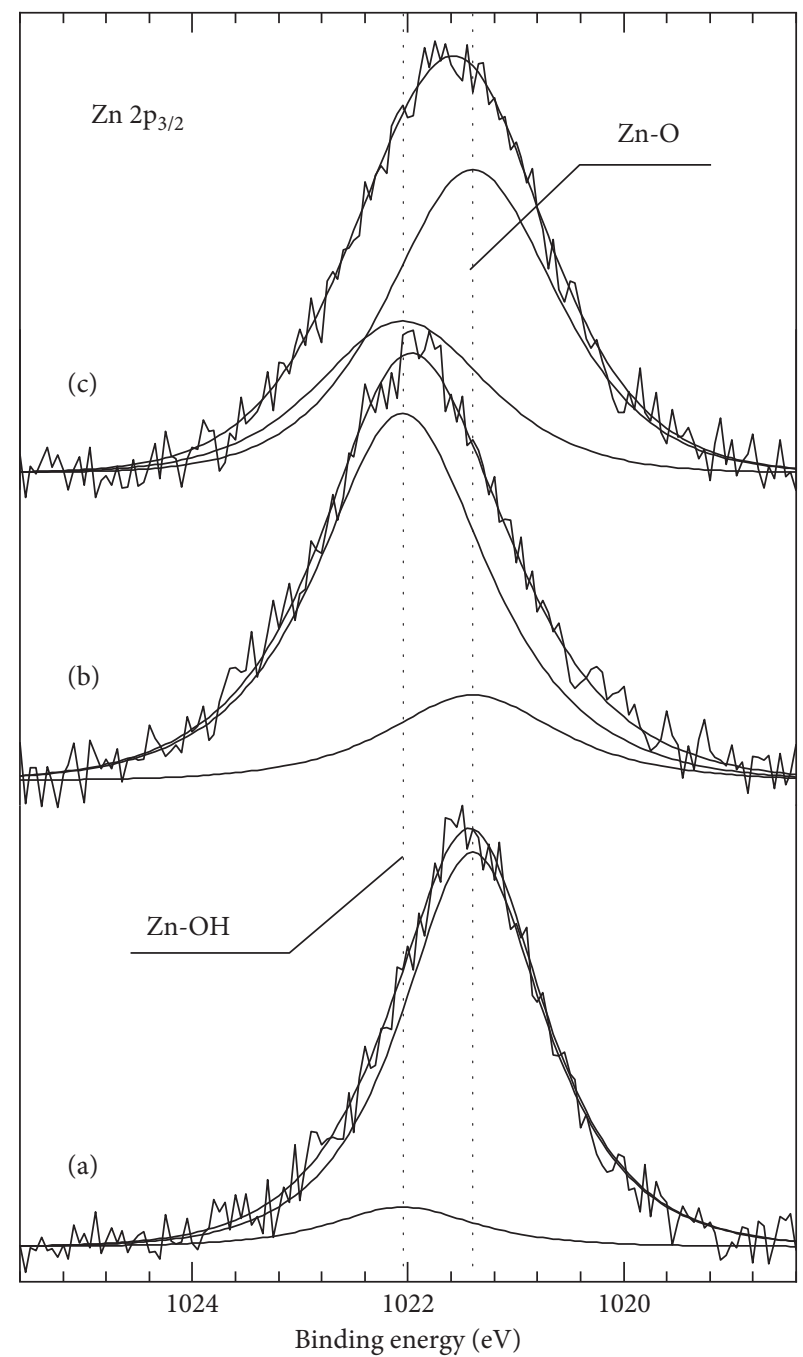

Figure 6: $\mathrm{Zn} 2 \mathrm{p}_{3 / 2}$ photoelectron spectra for $\mathrm{ZnO}$ (a) and $\mathrm{Zn}(\mathrm{OH})_{2}$ (b) in the as-received form and for $\mathrm{Zn}(\mathrm{OH})_{2}$ after $\mathrm{Ar}^{+}$sputter cleaning (c).

factor (RSF), greater full width at half maximum (FWHM), and, in particular, overlapping of $3 p_{3 / 2}$ and $3 p_{1 / 2}$ doublet components. However, the interpretation of zinc bonds, based on the $\mathrm{Zn} 3 \mathrm{p}$ spectra, becomes a necessity if, for example, zinc is buried under carbon (which is often the case with thicker layers of corrosion products). As stated above, large differences in the kinetic energies of $\mathrm{Zn} 2 \mathrm{p}$ and $\mathrm{Zn} 3 \mathrm{p}$ photoelectrons cause the sampling depth of the latter to be over three times greater. This allows to identify zinc bonds even when the $\mathrm{Zn} 2 \mathrm{p}$ main lines are not at all visible. For these purposes, the values of $\mathrm{Zn} 3 \mathrm{p}_{3 / 2}$ binding energies are presented in Table 2. During deconvolution of $\mathrm{Zn} 3 \mathrm{p}$ spectra (spectra not included here), earlier results of $\mathrm{Zn} 2 \mathrm{p}_{3 / 2}$ spectra deconvolution were used, getting their full compatibility.

$\mathrm{O} 1 \mathrm{~s}$ and $\mathrm{Zn} 2 \mathrm{p}_{3 / 2}$ photoelectron spectra for $\mathrm{ZnCO}_{3}$ are presented in Figure 7. The shape of the spectra and their FWHM values testify to high homogeneity of synthesized $\mathrm{ZnCO}_{3}$ powder. The binding energies of $\mathrm{O} 1 \mathrm{~s}, \mathrm{Zn} 2 \mathrm{p}_{3 / 2}$, and $\mathrm{C}$ 1s photoelectrons were estimated at 532.2, 1022.49, and $290.0 \mathrm{eV}$, respectively. 
TABLE 2: Binding and kinetic energies for selected photoelectrons and Auger electrons estimated on the basis of experimental spectra for $\mathrm{ZnO}, \mathrm{Zn}(\mathrm{OH})_{2}, \mathrm{Zn}_{5}(\mathrm{OH})_{8} \mathrm{Cl}_{2} \cdot \mathrm{H}_{2} \mathrm{O}, \mathrm{ZnCO}_{3}$, and $\mathrm{Zn}_{5}\left(\mathrm{CO}_{3}\right)_{2}(\mathrm{OH})_{6}$ powders.

\begin{tabular}{|c|c|c|c|c|c|c|c|c|}
\hline \multirow[t]{2}{*}{ Compound } & \multirow{2}{*}{$\begin{array}{c}\mathrm{Zn} 2 \mathrm{p}_{3 / 2} \\
(\mathrm{eV})\end{array}$} & \multirow{2}{*}{$\begin{array}{c}\text { Zn LMM } \\
(\mathrm{eV})\end{array}$} & \multicolumn{2}{|c|}{$\begin{array}{l}\text { Modified Auger parameter } \\
\qquad\left(\alpha^{\prime}\right)\end{array}$} & \multirow{2}{*}{$\begin{array}{c}\mathrm{Zn} 3 \mathrm{p}_{3 / 2} \\
(\mathrm{eV}) \\
\end{array}$} & \multicolumn{3}{|c|}{$\mathrm{O} 1 \mathrm{~s}$} \\
\hline & & & $(\mathrm{eV})$ & Reference & & $\mathrm{O}^{2-}{ }_{\text {lat }}$ & $\mathrm{OH}$ & $\mathrm{CO}_{3}$ \\
\hline $\mathrm{Zn}_{\text {foil }}{ }^{*}$ & 1021.18 & 992.65 & $\begin{array}{c}2013.83 \\
2013.8 \\
\end{array}$ & $\begin{array}{c}\text { This work } \\
{[11,28]}\end{array}$ & 87.88 & - & - & - \\
\hline $\mathrm{ZnO}$ & 1021.47 & 988.75 & $\begin{array}{c}2010.22 \\
2010.1 \\
2010.4\end{array}$ & $\begin{array}{c}\text { This work, }[11] \\
{[28,29]} \\
{[30]}\end{array}$ & 88.18 & 530.2 & 531.4 & - \\
\hline $\mathrm{Zn}(\mathrm{OH})_{2}$ & 1021.81 & 987.5 & $\begin{array}{c}2009.31 \\
2009.2 \\
2009 \\
2009.6\end{array}$ & $\begin{array}{c}\text { This work } \\
{[11]} \\
{[28]} \\
{[29]}\end{array}$ & 88.49 & 530.11 & 531.41 & - \\
\hline $\mathrm{Zn}_{5}(\mathrm{OH})_{8} \mathrm{Cl}_{2} \cdot \mathrm{H}_{2} \mathrm{O}$ & 1022.21 & 987.22 & 2009.43 & This work & 89.13 & 530.1 & 531.89 & - \\
\hline $\mathrm{ZnCO}_{3}$ & 1022.49 & 987.23 & $\begin{array}{c}2009.72 \\
2009.7\end{array}$ & $\begin{array}{c}\text { This work } \\
{[11,28]}\end{array}$ & 89.1 & - & - & 532.2 \\
\hline $\mathrm{Zn}_{5}\left(\mathrm{CO}_{3}\right)_{2}(\mathrm{OH})_{6}$ & 1021.88 & 987.9 & $\begin{array}{c}2009.78 \\
2009.7 \\
2009.6 \\
\end{array}$ & $\begin{array}{c}\text { This work } \\
{[11]} \\
{[28]}\end{array}$ & 88.68 & 530.05 & 531.35 & 532.05 \\
\hline
\end{tabular}

*Zinc foil (Sigma-Aldrich, Zn 99.99\%) for reference only.
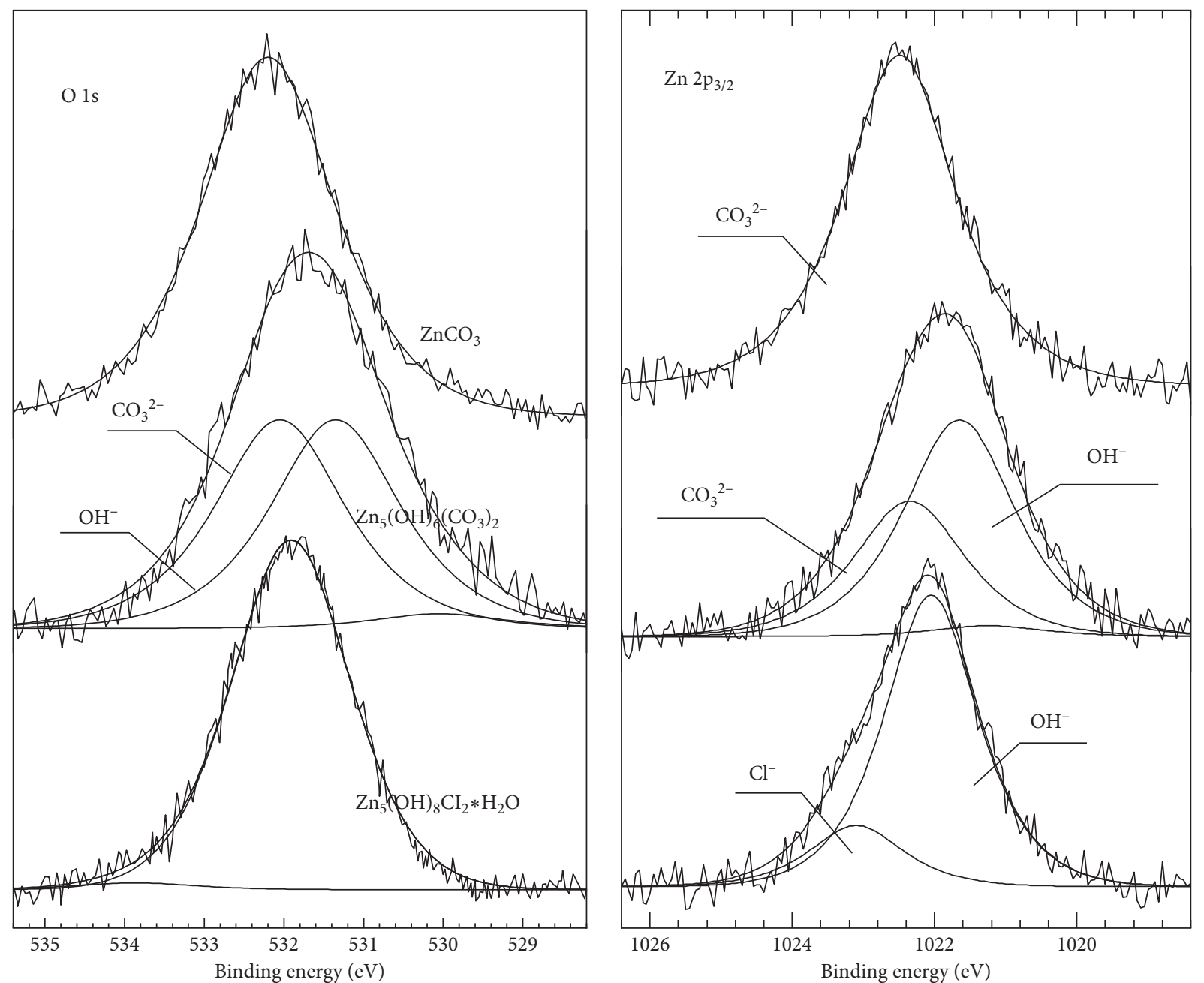

Figure 7: $\mathrm{O} 1 \mathrm{~s}$ and $\mathrm{Zn} 2 \mathrm{p}_{3 / 2}$ photoelectron spectra for $\mathrm{Zn}_{5}(\mathrm{OH})_{8} \mathrm{Cl}_{2} \cdot \mathrm{H}_{2} \mathrm{O}$, $\mathrm{ZnCO}_{3}$, and $\mathrm{Zn}_{5}\left(\mathrm{CO}_{3}\right)_{2}(\mathrm{OH})_{6}$ after Ar sputter cleaning. 


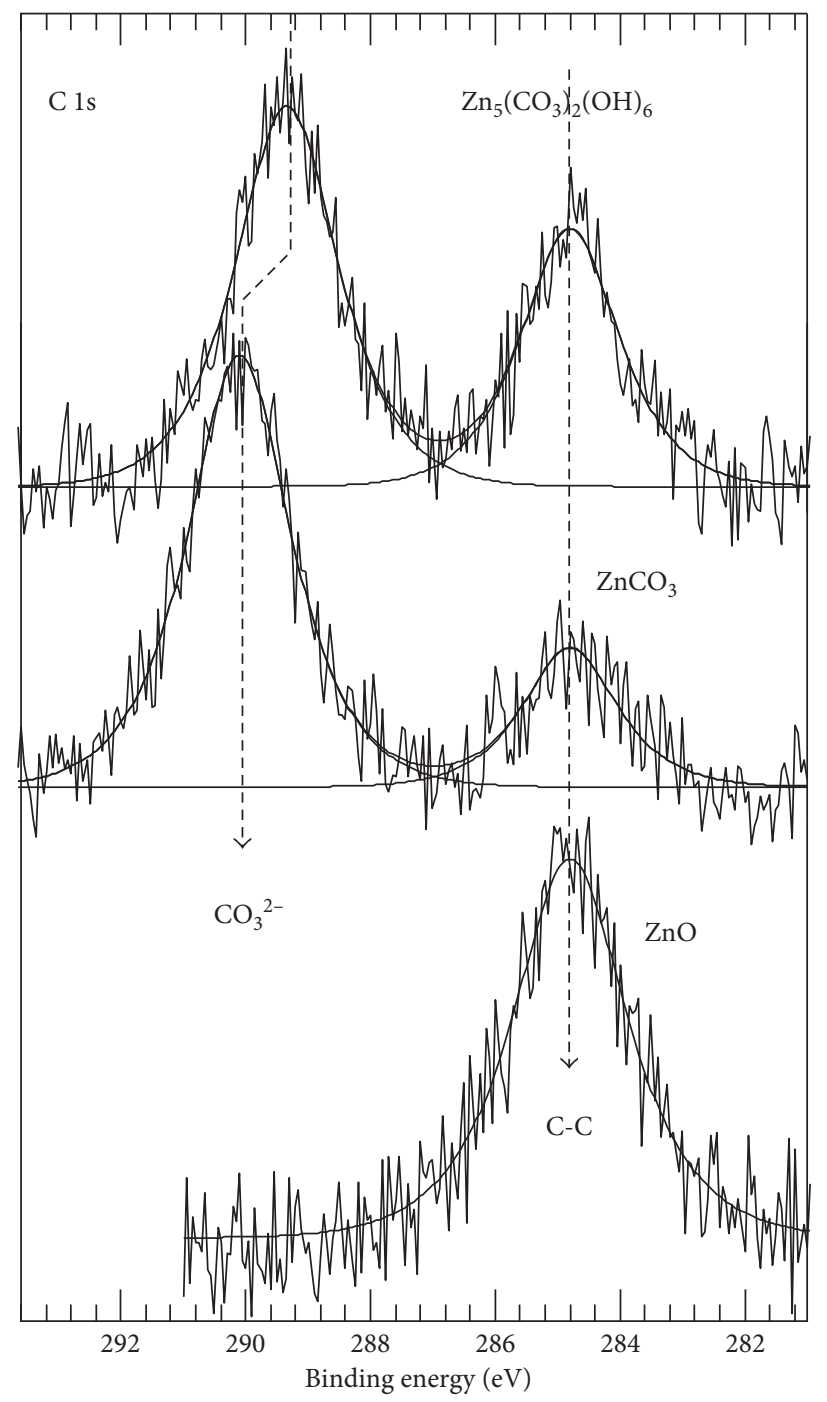

Figure 8: C 1s photoelectron spectra for $\mathrm{Zn}_{5}\left(\mathrm{CO}_{3}\right)_{2}(\mathrm{OH})_{6}, \mathrm{ZnCO}_{3}$, and $\mathrm{ZnO}$.

The gained knowledge about XPS spectra for $\mathrm{ZnO}$, $\mathrm{Zn}(\mathrm{OH})_{2}$, and $\mathrm{ZnCO}_{3}$ proved to be crucial in understanding the more complex spectra of real zinc corrosion products like $\mathrm{Zn}_{5}(\mathrm{OH})_{8} \mathrm{Cl}_{2} \cdot \mathrm{H}_{2} \mathrm{O}$ (simonkolleite) and $\mathrm{Zn}\left(\mathrm{CO}_{3}\right)_{2}(\mathrm{OH})$ (hydrozincite) (Figures 7-9). On the $\mathrm{O} 1 \mathrm{~s}$ spectrum of $\mathrm{Zn}_{5}(\mathrm{OH})_{8} \mathrm{Cl}_{2} \cdot \mathrm{H}_{2} \mathrm{O}$ dominates the component characteristic for the binding energy of oxygen in a hydroxyl group (maximum at $531.9 \mathrm{eV}$ ). In contrast, in the $\mathrm{O} 1 \mathrm{~s}$ spectrum for $\mathrm{Zn}\left(\mathrm{CO}_{3}\right)_{2}(\mathrm{OH})_{6}$, the highest (and comparable) share belongs to the component characteristic of the hydroxyl and carbonate groups. Similarly, in the $\mathrm{Zn} 2 \mathrm{p}_{3 / 2}$ spectra, the relevant components of zinc bonds with $\mathrm{OH}^{-}, \mathrm{CO}_{3}{ }^{2-}$, and $\mathrm{Cl}^{-}$groups were distinguished (Figure 7).

The $\mathrm{C} 1 \mathrm{~s}$ spectra were used to properly balance particular bonds in the analyzed compounds. In the case of $\mathrm{ZnCO}_{3}$ and $\mathrm{Zn}_{5}\left(\mathrm{CO}_{3}\right)_{2}(\mathrm{OH})_{6}$, deconvolution of $\mathrm{C}$ 1s spectra (Figure 8), taking into account the existence of the two (main) components: the carbon originating from carbonates $\left(\mathrm{CO}_{3}\right)$ and contamination carbon $(\mathrm{C}-\mathrm{C})$, allowed to estimate the content of "carbonate" carbon in $\mathrm{ZnCO}_{3}$ and $\mathrm{Zn}_{5}\left(\mathrm{CO}_{3}\right)_{2}(\mathrm{OH})_{6}$ to 19.6 and 9.8 at.\%, respectively (Table 3 ). For comparison, the $\mathrm{C} 1 \mathrm{~s}$ spectrum of $\mathrm{ZnO}$ does not contain any component of the "carbonate" on the side of higher binding energies (Figure 8). The carbonate component was also not found on the surface of $\mathrm{Zn}_{5}(\mathrm{OH})_{8} \mathrm{Cl}_{2} \cdot \mathrm{H}_{2} \mathrm{O}$, proving the high surface purity of the obtained standard (Figure 9). The spectral documentation of $\mathrm{Zn}_{5}(\mathrm{OH})_{8} \mathrm{Cl}_{2} \cdot \mathrm{H}_{2} \mathrm{O}$ was supplemented with $\mathrm{Cl} 2 \mathrm{p}$ spectrum and assigned $\mathrm{BE}=198.74$ and $200.34 \mathrm{eV}$ in $2 \mathrm{p}_{3 / 2}$ and $2 \mathrm{p}_{1 / 2}$ doublet, respectively, characteristic of alkali chloride.

XPS surface composition of $\mathrm{ZnO}, \mathrm{Zn}(\mathrm{OH})_{2}$, $\mathrm{Zn}_{5}(\mathrm{OH})_{8} \mathrm{Cl}_{2} \cdot \mathrm{H}_{2} \mathrm{O}, \mathrm{ZnCO}_{3}$, and $\mathrm{Zn}_{5}\left(\mathrm{CO}_{3}\right)_{2}(\mathrm{OH})_{6}$ powders prepared by the precipitation method and the shares of oxygen and zinc bonds based on deconvolution are shown in Table 3 . In each case, the results of the deconvolution were correlated to the stoichiometry of the studied compounds, whose structure was previously documented by XRD and FT-IR analysis.

\section{Conclusions}

In this work are summarized and compared the XPS and IR spectra for the chosen and the most common synthetic corrosion products of zinc in $\mathrm{NaCl}$ environment. The basic 


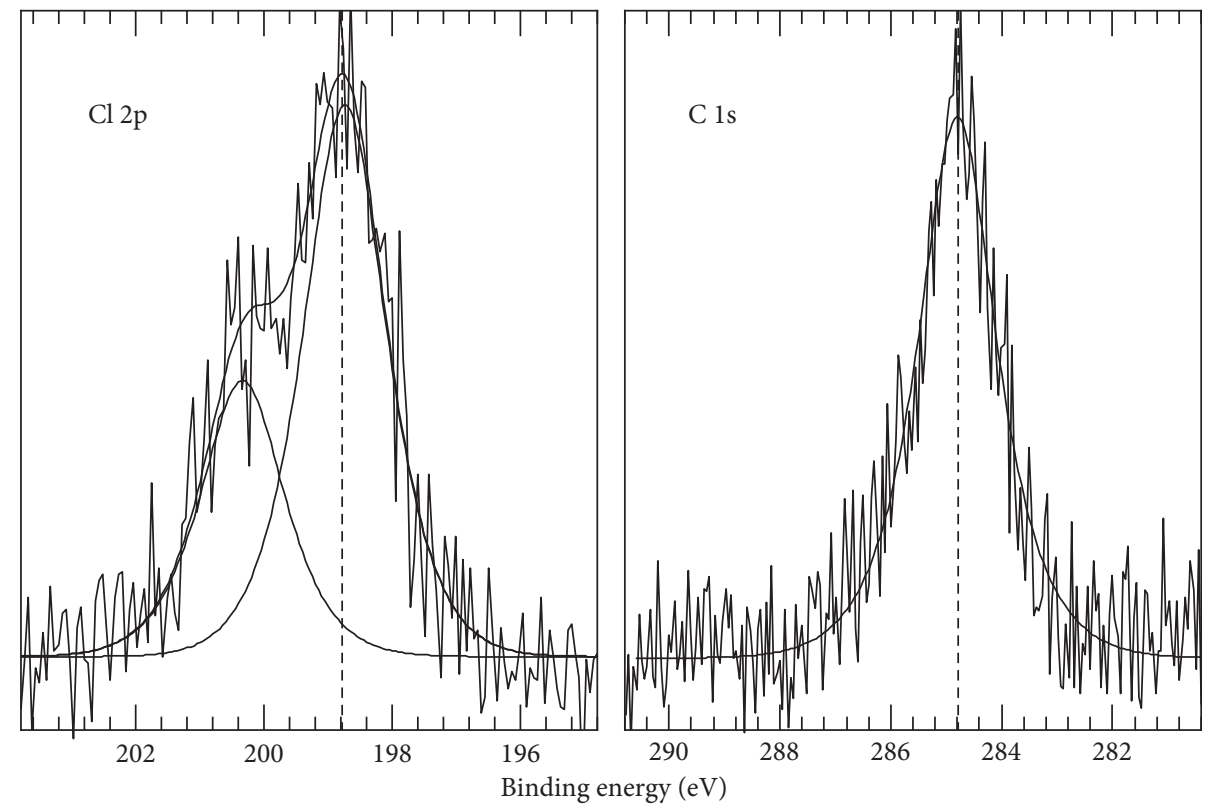

Figure 9: XPS Cl 2p and C 1s core-level spectra for $\mathrm{Zn}_{5}(\mathrm{OH})_{8} \mathrm{Cl}_{2} \cdot \mathrm{H}_{2} \mathrm{O}$.

TABLE 3: XPS surface composition of $\mathrm{ZnO}, \mathrm{Zn}(\mathrm{OH})_{2}, \mathrm{Zn}_{5}(\mathrm{OH})_{8} \mathrm{Cl}_{2} \cdot \mathrm{H}_{2} \mathrm{O}, \mathrm{ZnCO}_{3}$, and $\mathrm{Zn}_{5}\left(\mathrm{CO}_{3}\right)_{2}(\mathrm{OH})_{6}$ powders prepared by the precipitation method and shares of oxygen and zinc bonds.

\begin{tabular}{|c|c|c|c|c|c|c|c|c|c|c|c|}
\hline \multirow{2}{*}{ Compound } & \multicolumn{4}{|c|}{$\begin{array}{l}\text { The share of oxygen bonds with } \\
\text { regard to total oxygen }\end{array}$} & \multicolumn{4}{|c|}{ Atomic composition (at.\%) } & \multicolumn{3}{|c|}{$\begin{array}{l}\text { The share of zinc in the oxygen } \\
\text { bonds (at.\%) }\end{array}$} \\
\hline & $\mathrm{O}\left({ }^{2-}\right)$ & $\mathrm{CO}_{3}$ & $\mathrm{OH}$ & $\mathrm{H}_{2} \mathrm{O}$ & $\mathrm{C}_{\mathrm{CO}_{3}}$ & $\mathrm{O}$ & $\mathrm{Zn}$ & $\mathrm{Cl}$ & $-\mathrm{OH}$ & $-\mathrm{O}$ & $-\mathrm{CO}_{3} /-\mathrm{Cl}$ \\
\hline $\mathrm{ZnO}$ & 0.83 & - & 0.17 & - & - & 50.1 & 49.9 & - & 4.3 & 41.6 & - \\
\hline $\mathrm{Zn}(\mathrm{OH})_{2}$ & 0.10 & - & 0.90 & - & - & 64.2 & 35.8 & - & 28.9 & 6.4 & - \\
\hline $\mathrm{Zn}_{5}(\mathrm{OH})_{8} \mathrm{Cl}_{2} \cdot \mathrm{H}_{2} \mathrm{O}$ & 0.11 & - & 0.87 & 0.02 & - & 54.8 & 35.2 & 10.0 & 23.8 & 6.0 & 5.0 \\
\hline $\mathrm{ZnCO}_{3}$ & - & 1.00 & - & - & 19.6 & 61.8 & 18.6 & - & - & - & 18.6 \\
\hline $\mathrm{Zn}_{5}(\mathrm{OH})_{6}\left(\mathrm{CO}_{3}\right)_{2}$ & 0.05 & 0.48 & 0.48 & - & 9.80 & 62.1 & 28.1 & - & 14.7 & 3.1 & 9.8 \\
\hline
\end{tabular}

conclusion from the presented research is the statement that the surface composition of the investigated synthetic oxidation products: $\mathrm{ZnO}, \mathrm{Zn}(\mathrm{OH})_{2}, \mathrm{Zn}_{5}(\mathrm{OH})_{8} \mathrm{Cl}_{2} \cdot \mathrm{H}_{2} \mathrm{O}$, $\mathrm{ZnCO}_{3}$, and $\mathrm{Zn}_{5}\left(\mathrm{CO}_{3}\right)_{2}(\mathrm{OH})_{6}$, corresponds well with their stoichiometry despite the presence of surface contamination. Another important conclusion is also that obtaining the standard spectra of pure $\left(\mathrm{Zn}(\mathrm{OH})_{2}\right.$ free $)$ zinc oxide and other ( $\mathrm{ZnO}$-free) zinc hydroxyl compounds is in practice extremely difficult, even though the XRD phase analysis indicates the phase purity of these substances. It has been shown that despite the complexity of the recorded photoelectron spectra, after the adoption of certain assumptions, one can estimate the corrosion products of zinc coatings. This work collects the binding energies of $\mathrm{Zn} 2 \mathrm{p}_{3 / 2}, \mathrm{O} 1 \mathrm{~s}$, and $\mathrm{Zn} \mathrm{3p}$ photoelectrons, together with Zn LMM kinetic energies, modified Auger parameters $\left(\alpha^{\prime}\right)$, and corresponding characteristic infrared absorbance bands. Therefore, it can be helpful in the interpretation of corrosion processes of zinc alloy coatings in environment containing chloride ions.

\section{Data Availability}

Raw measurement data will be available (ASCII format) for the reader upon request.

\section{Conflicts of Interest}

The authors declare that there are no conflicts of interest regarding the publication of this paper.

\section{Acknowledgments}

The work was cofinanced by a statutory activity subsidy from the Polish Ministry of Science and Higher Education for the Faculty of Engineering and Economics of Wroclaw University of Economics (Grant number 203075/E-311/S/2017) and the Faculty of Chemistry of Wroclaw University of Science and Technology, Department of Advanced Material Technologies in 2017/2018 year (Grant number 0401/0200/17). The author (Juliusz Winiarski) would like to thank Ph.D. Alicja Stankiewicz from Edinburgh Napier University (GB) for sharing the FT-IR spectrometer with ATR cell during the research.

\section{References}

[1] K. Kanda and K. Saijo, "Chemical state analysis of Zn-Co-Mo electroplated layers by x-ray photoelectron spectroscopy," Journal of the Metal Finishing Society of Japan, vol. 35, no. 5, pp. 230-235, 1984. 
[2] B. Szczygieł, A. Laszczyńska, and W. Tylus, "Influence of molybdenum on properties of $\mathrm{Zn}-\mathrm{Ni}$ and $\mathrm{Zn}-\mathrm{Co}$ alloy coatings," Surface and Coatings Technology, vol. 204, no. 9-10, pp. 1438-1444, 2010.

[3] J. Winiarski, W. Tylus, K. Winiarska et al., "The influence of molybdenum on the corrosion resistance of ternary $\mathrm{Zn}-\mathrm{Co}-$ Mo alloy coatings deposited from citrate-sulphate bath," Corrosion Science, vol. 91, pp. 330-340, 2015.

[4] J. Winiarski, W. Tylus, and B. Szczygieł, "EIS and XPS investigations on the corrosion mechanism of ternary $\mathrm{Zn}-$ Co-Mo alloy coatings in $\mathrm{NaCl}$ solution," Applied Surface Science, vol. 364, pp. 455-466, 2016.

[5] J. Winiarski, W. Tylus, M. S. Krawczyk, and B. Szczygieł, "The influence of molybdenum on the electrodeposition and properties of ternary $\mathrm{Zn}-\mathrm{Fe}-\mathrm{Mo}$ alloy coatings," Electrochimica Acta, vol. 196, pp. 708-726, 2016.

[6] J. Winiarski, A. Leśniewicz, P. Pohl, and B. Szczygieł, “The effect of $\mathrm{pH}$ of plating bath on electrodeposition and properties of protective ternary Zn-Fe-Mo alloy coatings," Surface and Coatings Technology, vol. 299, pp. 81-89, 2016.

[7] A. Mahapatro, T. D. Matos Negrón, and A. Nguyen, "Spectroscopic evaluations of interfacial oxidative stability of phosphonic nanocoatings on magnesium," Journal of Spectroscopy, vol. 2015, Article ID 350630, 8 pages, 2015.

[8] I. Odnewall, "Atmospheric corrosion of field exposed zinc-a multianalytical characterization of corrosion products from initial films to fully developed layers," Doctoral thesis, Royal Institute of Technology, Stockholm, Sweden, 1994.

[9] B. E. Conway and D. C. W. Kannangara, "Zinc oxidation and redeposition processes in aqueous alkali and carbonate solutions II. Distinction between dissolution and oxide film formation processes," Journal of Electrochemical Society, vol. 134, no. 4, pp. 906-918, 1987.

[10] S. Thomas, N. Birbilis, M. S. Venkatraman, and I. S. Cole, "Self-repairing oxides to protect zinc: review, discussion and prospects," Corrosion Science, vol. 69, pp. 11-22, 2013.

[11] L. S. Dake, D. R. Baer, and J. M. Zachara, "Auger parameter measurements of zinc compounds relevant to zinc transport in the environment," Surface and Interface Analysis, vol. 14, no. 1-2, pp. 71-75, 1989.

[12] G. Deroubaix and P. Marcus, "X-ray photoelectron spectroscopy analysis of copper and zinc oxides and sulphides," Surface and Interface Analysis, vol. 18, no. 1, pp. 39-46, 1992.

[13] J. Duchoslav, R. Steinberger, M. Arndtt, and D. Stifter, "XPS study of zinc hydroxide as a potential corrosion product of zinc: rapid X-ray induced conversion into zinc oxide," Corrosion Science, vol. 82, pp. 356-361, 2014.

[14] A. S. Shaporev, V. K. Ivanov, A. E. Baranchikov, O. S. Polezhaeva, and Y. D. Tret'yakov, "ZnO formation under hydrothermal condition from zinc hydroxide compounds with various chemical histories," Russian Journal of Inorganic Chemistry, vol. 52, no. 12, pp. 1811-1816, 2007.

[15] W. Zhang and K. Yanagisawa, "Hydrothermal synthesis of zinc hydroxide chloride sheets and their conversion to $\mathrm{ZnO}$," Chemistry of Materials, vol. 19, no. 9, pp. 2329-2334, 2007.

[16] W. Wu and Q. Jing, "Preparation of nanocrystalline zinc carbonate and zinc oxide via solid-state reaction at room temperature," Materials Letters, vol. 60, no. 21-22, pp. 2791-2794, 2006.

[17] J. I. Langford and A. J. C. Wilson, "Scherrer after sixty years: a survey and some new results in the determination of crystallite size," Journal of Applied Crystallography, vol. 11, no. 2, pp. 102-113, 1978.

[18] O. Garcia-Martinez, E. Vila, J. L. Martin de Vidales et al., "On the thermal decomposition of the zinc(II) hydroxide chlorides
$\mathrm{Zn}_{5}(\mathrm{OH})_{8} \mathrm{Cl}_{2} \cdot \mathrm{H}_{2} \mathrm{O}$ and $\beta-\mathrm{Zn}(\mathrm{OH}) \mathrm{Cl}$," Journal of Materials Science, vol. 29, no. 20, pp. 5429-5434, 1994.

[19] A. Kajbafvala, S. Zanganeh, E. Kajbafvala et al., "Microwaveassisted synthesis of narcis-like zinc oxide nanostructures," Journal of Alloys and Compounds, vol. 497, no. 1-2, pp. 325-329, 2010.

[20] H. D. Lutz, C. Jung, R. Mörtel, H. Jacobs, and R. Stahl, "Hydrogen bonding in solid hydroxides with strongly polarising metal ions, $\beta-\mathrm{Be}(\mathrm{OH})_{2}$ and $\varepsilon-\mathrm{Zn}(\mathrm{OH})_{2}$," Spectrochimica Acta Part A, vol. 54, no. 7, pp. 893-901, 1998.

[21] O. K. Srivastava and E. A. Secco, "Studies on metal hydoxy compounds. II. Infrared spectra of zinc derivatives $\varepsilon-\mathrm{Zn}(\mathrm{OH})_{2}$, $\beta$ - ZnOHCl, $\mathrm{ZnOHF}, \mathrm{Zn}_{5}(\mathrm{OH})_{8} \mathrm{Cl}_{2}$, and $\mathrm{Zn}_{5}(\mathrm{OH})_{8} \mathrm{Cl}_{2} \cdot \mathrm{H}_{2} \mathrm{O}$," Canadian Journal of Chemistry, vol. 45, no. 6, pp. 585-588.

[22] J. Sithole, B. D. Ngom, S. Khamlich et al., "Simonkolleite nano-platelets: synthesis and temperature effect on hydrogen gas sensing properties," Applied Surface Science, vol. 258, no. 20, pp. 7839-7843, 2012.

[23] M. C. Hales and R. L. Frost, "Synthesis and vibrational spectroscopic characterisation of synthetic hydrozincite and smithsonite," Polyhedron, vol. 26, no. 17, pp. 4955-4962, 2007.

[24] M. Bucca, M. Dietzel, J. Tang, A. Leis, and S. J. Köhler, "Nucleation and crystallization of otavite, witherite, calcite, strontianite, hydrozincite and hydrocerussite by $\mathrm{CO}_{2}$ membrane diffusion technique," Chemical Geology, vol. 266, no. 34, pp. 143-156, 2009.

[25] M. Bitenc, M. Marinšek, and Z. C. Orel, "Preparation and characterization of zinc hydroxide carbonate and porous zinc oxide particles," Journal of European Ceramic Society, vol. 28, no. 15, pp. 2915-2921, 2008.

[26] D. Stoilova, V. Koleva, and V. Vassileva, "Infrared study of some phase of malachite $\left(\mathrm{Cu}_{2}(\mathrm{OH})_{2} \mathrm{CO}_{3}\right)$-hydrozincite $\left(\mathrm{Zn}_{5}(\mathrm{OH})_{6}\left(\mathrm{CO}_{3}\right)_{2}\right)$ series," Spectrochemica Acta Part A, vol. 58, no. 9, pp. 2051-2059, 2002.

[27] S. Tougard, QUASES ${ }^{\mathrm{TM}}$, Software for IMFP calculation using TPP2M formulae, 2010.

[28] W. Furbeth and M. Stratmann, "The delamination of polymeric coatings from electrogalvanised steel-a mechanistic approach: part 1: delamination from a defect with intact zinc layer," Corrosion Science, vol. 43, no. 2, pp. 207-227, 2001.

[29] M. C. Biesinger, L. W. M. Lau, A. R. Gerson, and R. S. C. Smart, "Resolving surface chemical states in XPS analysis of first row transition metals, oxides and hydroxides: Sc, Ti, V, Cu and Zn," Applied Surface Science, vol. 257, no. 3 , pp. 887-898, 2010.

[30] S. Bera, S. Dhara, S. Velmurugan, and A. K. Tyagi, "Analysis on binding energy and auger parameter for estimating size and stoichiometry of $\mathrm{ZnO}$ nanorods," International Journal of Spectroscopy, vol. 2012, Article ID 371092, 4 pages, 2012. 

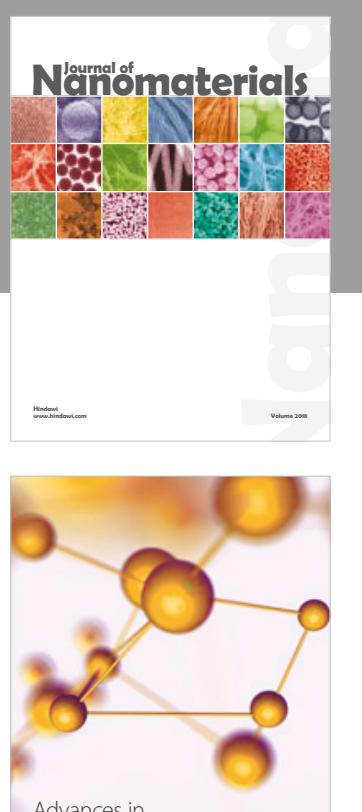

Physical Chemistry
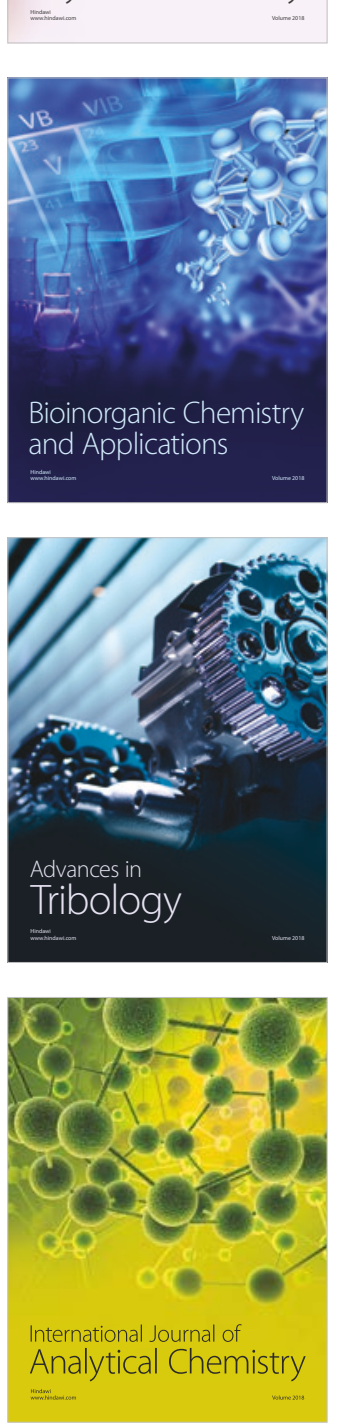

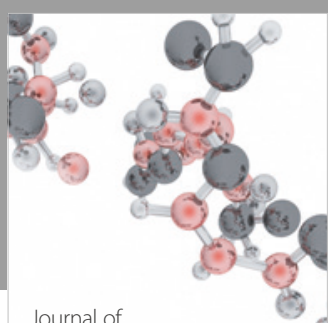

Analytical Methods

in Chemistry

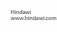

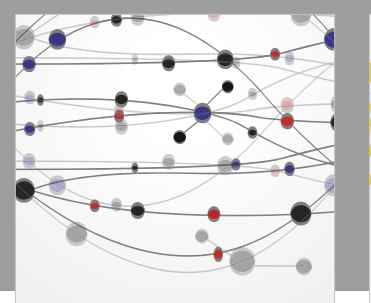

The Scientific World Journal

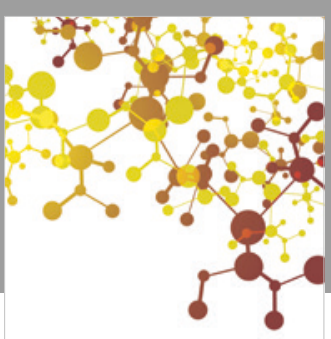

Journal of

Applied Chemistry
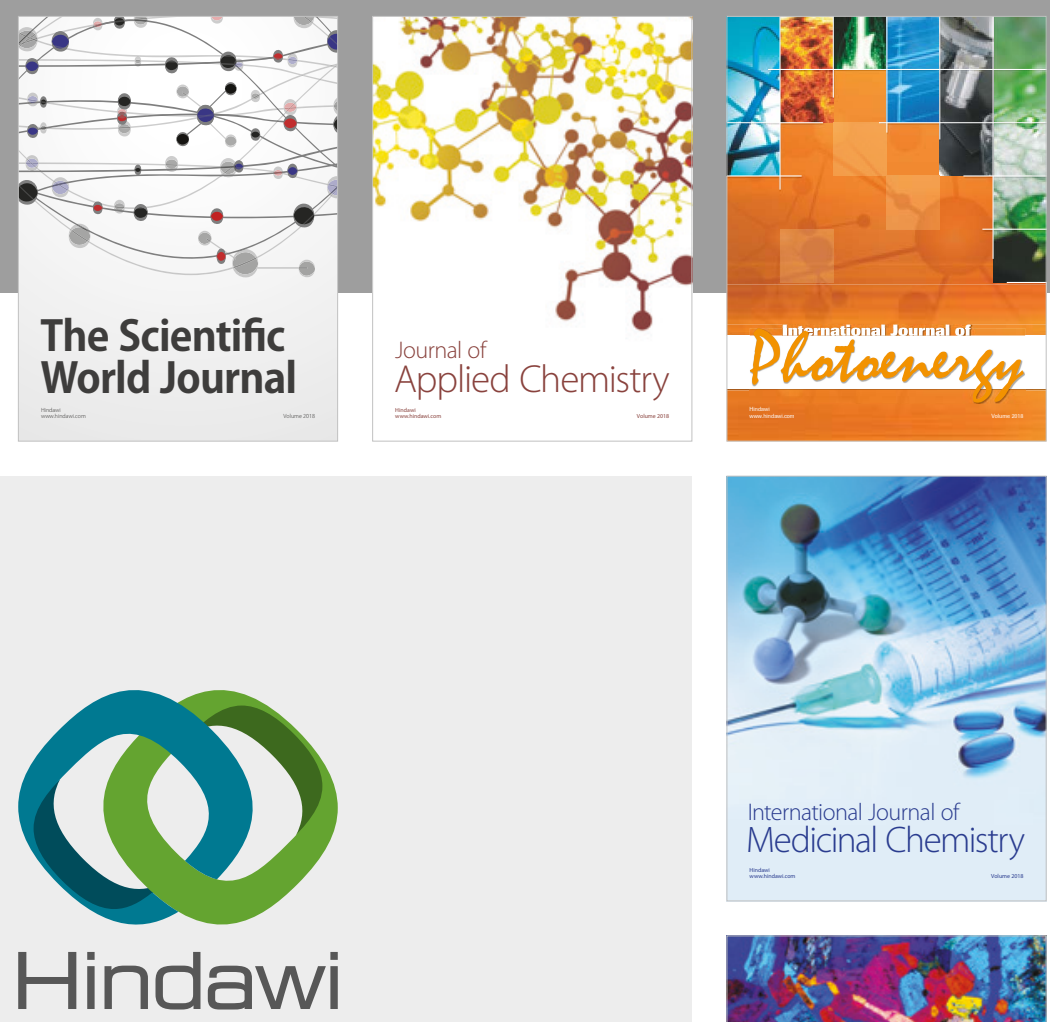

Submit your manuscripts at

www.hindawi.com
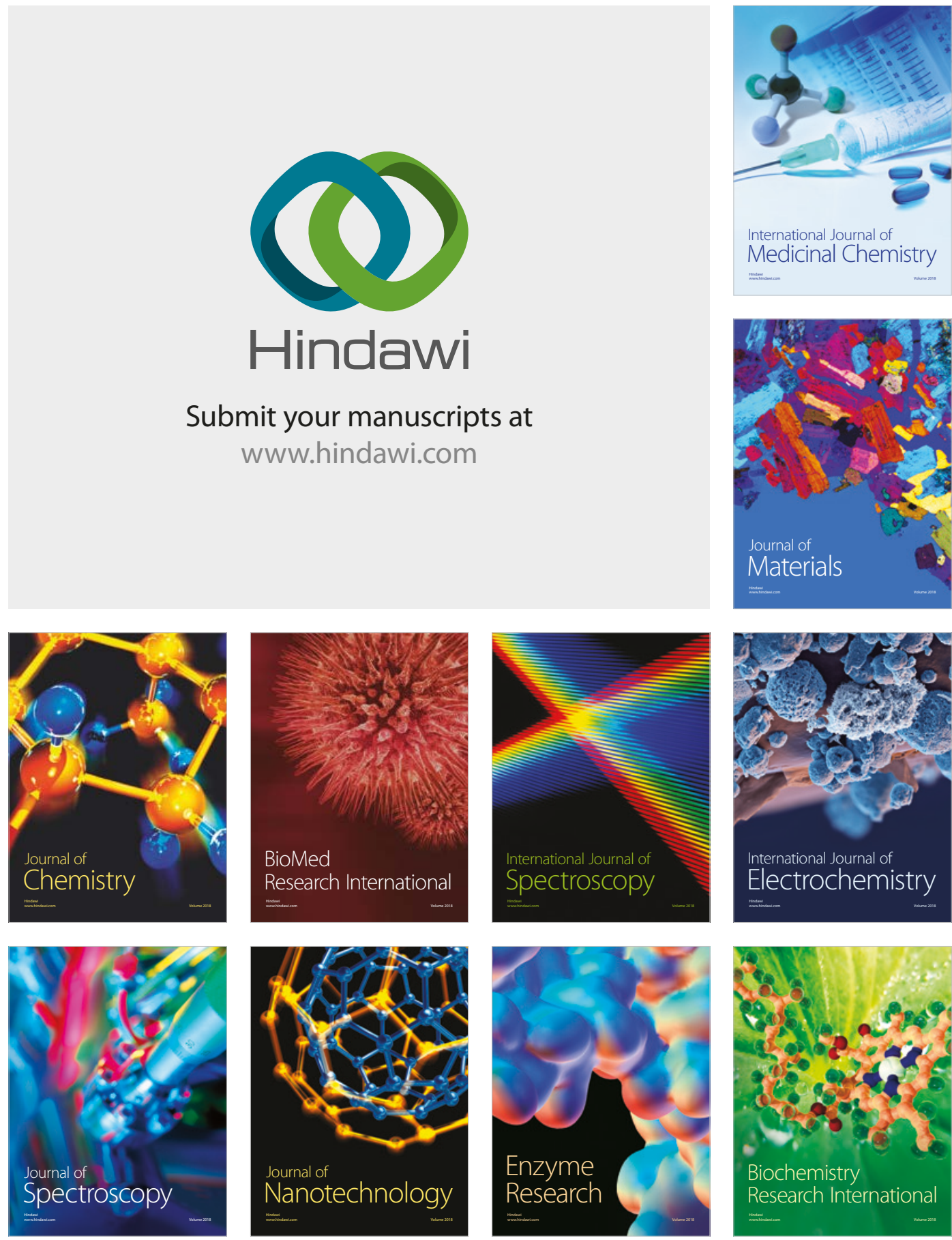
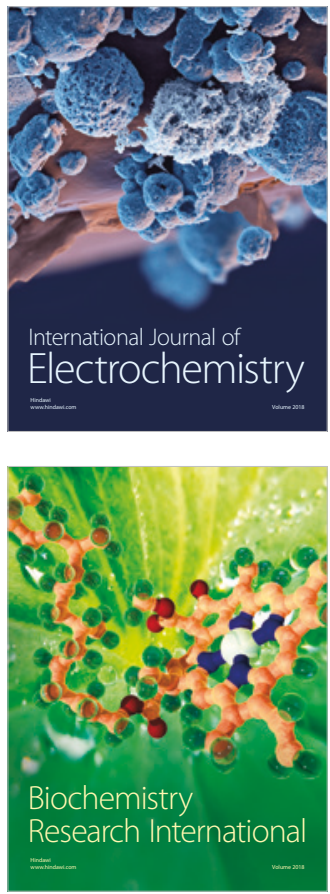